\title{
Coastal dynamics under conditions of rapid sea-level rise: Late Pleistocene to Early Holocene evolution of barrier-lagoon systems on the northern Adriatic shelf (Italy)
}

\author{
Joep E.A. Storms ${ }^{a,{ }^{*}}$, Gert Jan Weltje ${ }^{a}$, Guido J. Terra ${ }^{b}$, Antonio Cattaneo ${ }^{c}$ and Fabio \\ Trincardi $^{\mathrm{d}}$
}

\author{
${ }^{a}$ Faculty of Civil Engineering and Geosciences, Delft University of Technology, Section Applied Geology, PO Box \\ 5028, NL-2600GA Delft, The Netherlands \\ ${ }^{\mathrm{b}}$ Physics Department, Royal Netherlands Institute for Sea Research (NIOZ), PO Box 59, NL-1790AB Den Burg, \\ The Netherlands \\ ${ }^{c}$ IFREMER-Centre de Brest, Département Géosciences Marines, BP 70, F-29280 Plouzané, France \\ ${ }^{\mathrm{d}}$ Istituto di Scienze Marine-ISMAR (CNR), Via Gobetti 101, I-40129 Bologna, Italy \\ *: Corresponding author : Storms J., email address : j.e.a.storms@tudelft.nl
}

\begin{abstract}
:
This multidisciplinary case study of two preserved barrier systems combined the analysis of radiocarbon datings, grain-size distributions, high-resolution seismics, and shelf bathymetry with reconstructions of palaeo-environmental conditions (tides, waves, sea-level change) and forward modelling of barrier-lagoon systems, to provide an integrated view of the coastal transgressive evolution of a large sector of the northern Adriatic shelf between 15 and 8 ka BP. Palaeoenvironmental reconstructions point to increased tidal amplitude, low-energy wave climate and high rates of sea-level rise (up to $60 \mathrm{~mm} / \mathrm{a}$ ) during the formation of the oldest preserved barrier system (not, vert, similar90 m water depth; 14.3 cal ka BP). A younger barrier system (42 m water depth; $10.5 \mathrm{cal}$ ka BP) formed under conditions of lower tidal amplitude, higher wave energy and a lower rate of sealevel rise $(10 \mathrm{~mm} / \mathrm{a})$.
\end{abstract}

Forward modelling suggests that the probability of barrier-island overstepping during transgression is inversely proportional to tidal amplitude, if all other factors are assumed equal. The oldest barrierlagoon system developed under conditions of large tidal amplitude, which permitted rapid transgression. However, this system apparently failed to keep up with the anomalously high rate of sea-level rise resulting from melt-water pulse $1 \mathrm{~A}$. The youngest barrier system appears to have drowned in place due to antecedent topography. As the barrier system transgressed over an ancient Pleistocene alluvial plain, the rapid increase in backbarrier accommodation caused an abrupt disequilibrium between shoreface and backbarrier sedimentation, which led to barrier overstepping. Although BarSim modelling indicates that tidal deposition can reduce the probability of barrier overstepping, there are other driving mechanisms (in our case extremely rapid sea-level rise and antecedent topography), which are more determinative in explaining the transgressive coastal evolution of barrier-lagoon systems in the northern Adriatic Sea.

Grain-size analysis of shoreface deposits sampled above the transgressive ravinement surface across the northern Adriatic shelf indicate a distinct relation between the sediment grain size and the rate of sea-level rise during deposition, which implies that progressive sorting must have been highly effective.

Keywords: sea-level rise, transgression, barrier-lagoon system, tidal amplification, forward modelling, progressive sorting. 


\section{Introduction}

Late Quaternary clastic transgressive coasts often consist of typical barrier-lagoon systems that continuously migrate landwards as sea level rises (e.g., Swift, 1968; Belknap and Kraft, 1981; Nummedal and Swift, 1987). This type of transgression (continuous retreat; Swift et al., 1991) is generally accepted as the dominant type of retreat. However, Rampino and Sanders $(1980,1982,1983)$ describe a more controversial discontinuous retreat model (see discussions by Swift and Moslow, 1982; Leatherman, 1983) which assumes that a barrier system may be overstepped if the rate of sea-level rise is fast enough to drown the complete barrier in place while the shoreline steps landward. Rampino and Sanders (1980) lend credence to their theory by identification of offshore lagoonal deposits and bars, but they were not the first to describe the overstepping theory. Curray (1964) and Swift (1968) described a mechanism whereby barriers tend to grow upward during transgression until their enlarged lagoons trap so much sediment that the barrier is overstepped. Shoreface reworking generally destroys all evidence of the mode of retreat, thus leaving little evidence for the discontinuous retreat model. However, Forbes et al. (1991) illustrated barrier overstep for gravel barriers while Gardner et al., 2005 and Gardner et al., 2007 show preserved barriers at the outer shelf from high-resolution multibeam surveys. Here we present a new dataset based on a palaeo-environmental reconstruction for the Northern Adriatic Shelf which may shed a new light on the discussion of barrier overstep versus continuous retreat.

109

The Adriatic Sea is a low-gradient shelf sea in which sediment accumulated during the last transgression to form a continuous record in the centre of the basin and a set of discrete sediment bodies on the shelf. The latter are represented by two isolated areas comprising preserved barrier-lagoon deposits, which originated during the Late Pleistocene and Holocene sea-level rise (Trincardi et al., 1994; Correggiari et al., 1996a; Cattaneo and Trincardi, 1999). The barrier-lagoon deposits occur at different

116 present-day water depths. They are separated from one another by a distance of more 117 than $150 \mathrm{~km}$ and by a time interval of nearly 5000 years. Each of the sediment bodies 118 represents a snapshot of coastal evolution during the post-glacial sea-level rise which 119 started around 18 ka BP (Fairbanks, 1989; Bard et al., 1996). 
121 A comparative analysis of the two barrier-lagoon systems was carried out by means of

122 a multidisciplinary approach in which analysis of various types of data (shallow

123 seismics, core descriptions, grain-size distributions and radiocarbon dating) was

124 combined with process-response simulation of barrier-lagoon systems under

125 conditions of rapid sea-level rise. Forward modelling is based on an adaptation of

126 BarSim (Storms, 2003). The inferred rates of post-glacial sea-level rise under which

127 the two systems evolved far exceeded any observed in historical times, which

128 indicates that these isolated barrier-lagoon systems cannot be directly compared to

129 modern coastal environments. However, understanding their dynamics is essential

130 since they provide well-documented ancient analogues to possible future scenarios of

131 coastal evolution under conditions of accelerated sea-level rise. In the Adriatic region,

132 the isolated sediment bodies are also of commercial interest, because they represent

133 exploitable resources of clean sand.

134

\section{Geological setting of the Northern Adriatic shelf}

136

137 The Adriatic Sea is a mid-latitude semi-enclosed rectangular basin bordered to the

138 Southwest by the Apennines, to the North by the Alps and to the Northeast by the

139 Dinaric Alpes. The Adriatic Sea is on average $200 \mathrm{~km}$ wide and approximately 800

$140 \mathrm{~km}$ long (Fig. 1). It may be subdivided into three bathymetrically distinct regions. The

141 northern region consists of a $300 \mathrm{~km}$ long south-sloping low-gradient continental

142 shelf bordered by the 120 -m isobath. The adjacent middle region comprises several

143 slope basins, including the Meso-Adriatic Depression (=MAD), which has a

144 maximum water depth of $260 \mathrm{~m}$. The southern region, which is connected to the

145 Mediterranean Sea by the narrow Strait of Otranto, is much deeper (up to $1200 \mathrm{~m}$ ).

146 The shelf North of the Gargano Promontory is a modern foreland basin related to the

147 Cenozoic emplacement of the Apenninic chain (Argnani et al., 1991). The depth of

148 the base of the Pliocene increases landward from 1 to $3 \mathrm{~km}$, which indicates high rates

149 of tectonically induced flexural subsidence north of the Gargano Promontory during

150 the Quaternary (Pieri and Groppi, 1981; Waschbusch and Royden, 1992; Ridente and

151 Trincardi, 2002). Subsidence patterns in the Northern Adriatic basin over the last 15

152 ka are poorly constrained (Pirazzoli, 2005). 
154 The Northern Adriatic shelf is characterized by a very low gradient in its northern and 155 central parts, and a high gradient in the southwest. During the Last Glacial Maximum 156 (=LGM), an approximately $300 \mathrm{~km}$ wide stretch of the Northern Adriatic shelf was

157 subaerially exposed. The drainage network on this large alluvial plain likely

158 comprised a "Mega Po" trunk river, with the Alpine and Apenninic rivers as

159 tributaries. The system terminated in a lowstand delta located at the northern edge of

160 the MAD (Trincardi and Correggiari, 2000; Ridente and Trincardi, 2006). High-

161 resolution seismic surveys have indicated the presence of isolated incised valleys at

162 various locations on the shelf, and systematic mapping of the Late-Pleistocene palaeo-

163 Po valley is being conducted within the national (Italian) project Cartografia Marina

164 (Trincardi and Argnani, 2001; Trincardi et al., 2004). Preliminary work shows that

165 incised valleys and channels are not continuous but appear locally deepened or

166 completely erased in other areas and depth intervals (Trincardi et al., 1994). Prior to 9

$167 \mathrm{ka} \mathrm{BP}$, sedimentation in the coastal plain (the present onshore) was restricted to the

168 incised valley of the Po and its tributaries, while pedogenesis took place on the

169 interfluves (Amorosi et al., 2003). Sediment supply by the Po River and various

170 smaller Apenninic and Alpine rivers has been significant during the Late Quaternary

171 sea-level rise (Kettner and Syvitski, in press), whereas sediment input from the

172 Dinarides has been negligible due to their carbonatic lithology and the presence of

173 nearshore structural basins acting as sediment traps. The majority of the fluvial

174 sediment, which was fine grained, has been trapped in an elongated mud wedge along

175 the high-gradient south-western shelf (Fig. 1; Cattaneo et al., 2003) due to the

176 presence of an anti-clockwise circulation pattern. This coast-hugging oceanic current

177 reflects a combination of wind forcing by Bora and Sirocco and thermohaline

178 circulation (Decouttere et al., 1998). It is inferred to have been active since the late

179 Pleistocene, 15 ka BP (Trincardi et al., 1994; Correggiari et al., 1996b; Cattaneo and

180 Trincardi, 1999). Consequently, the northern part of the shelf acted as a bypass zone

181 and has been starved of sediment during the past $15 \mathrm{ka}$.

182

183 The late-Quaternary transgressive deposits of the northern shelf consists of two main

184 isolated shallow-marine sediment bodies located at approximately $90 \mathrm{~m}$ and $42 \mathrm{~m}$

185 below present sea level (Fig. 2). These isolated sediment bodies are interpreted as

186 preserved barrier-lagoon complexes. The average rate of transgression between the

$187120 \mathrm{~m}$ and $26 \mathrm{~m}$ isobath, corresponding to the inferred coastline positions at $19 \mathrm{ka} \mathrm{BP}$ 
188 (LGM) and $9 \mathrm{ka} \mathrm{BP}$, respectively, was $28 \mathrm{~m} / \mathrm{a}$. The rate of transgression was even higher during the two melt-water pulses (Fairbanks, 1989; Clark et al., 2002; Liu and Milliman, 2004). Such rates of transgression far exceed any observed during historical times, which indicates that these ancient barrier-lagoon complexes cannot be directly compared to modern depositional systems.

193

\section{Palaeoceanographic conditions}

195

\subsection{Sea-level history}

197

Although the Mediterranean and Adriatic seas are semi-enclosed basins, they remained connected to the Atlantic Ocean during the LGM. This implies that the eustatic sea-level curve should be applicable to the Adriatic Sea. Coastal dynamics are highly sensitive to changes in the rate of sea-level rise, especially on low-gradient shelves such as the Northern Adriatic. It is therefore important to constrain the rates of sea-level rise during the time interval corresponding to the formation of the barrierlagoon systems as accurately as possible. Liu and Milliman (2004) presented new data to refine the depth ranges and timing of melt water pulses MWP-1A (96 to $76 \mathrm{~m}$ below present sea level; 14.3 to14.0 ka cal BP) and MWP-1B (58 to $45 \mathrm{~m}$ below present sea level; 11.5 to $11.2 \mathrm{ka}$ cal $\mathrm{BP}$ ). As the time interval of interest to this study is between $15 \mathrm{ka} \mathrm{BP}$ and $8 \mathrm{ka} \mathrm{BP}$, we used the Liu and Milliman (2004) curve, and extended it with data from Fleming et al. (1998) for the interval between $10 \mathrm{ka}$ BP and 8 ka BP (Fig. 3).

212 Reconstruction of a relative sea-level curve applicable to the Northern Adriatic 213 requires that the eustatic signal be combined with information on local subsidence due 214 to tectonics, sediment loading and compaction. Although such information is 215 available for some areas of the northern Adriatic, for instance the modern Po plain, 216 where subsidence rates are locally up to $2 \mathrm{~mm} / \mathrm{a}$ (Brunetti et al., 1998; Carminati and 217 Di Donato, 1999), there is no comprehensive analysis of vertical movements in the 218 offshore (Pirazzoli, 2005). In the Venice area, the average subsidence rate over the 219 past $400 \mathrm{ka}$ is estimated to be $0.36 \mathrm{~mm} / \mathrm{a}$, based on data from a $950 \mathrm{~m}$ deep core (Kent 220 et al., 2002). About $60 \mathrm{~km}$ south of the present Po delta, the Eemian shoreline ( 120 $221 \mathrm{ka} \mathrm{BP}$ ) is identified at $120 \mathrm{~m}$ depth below the modern coastal plain of Ravenna 
(Amorosi et al., 1999). This would suggest an average combined subsidence and compaction rate of about $1 \mathrm{~mm} / \mathrm{a}$. In the north-eastern part of the Adriatic, however, relative sea level appears to have been stable during the late Holocene (Pirazzoli, 2005). Subsidence rates further to the south are poorly known, but the presence of a palaeo-shoreline (lowstand delta) at 120 m water depth (Trincardi and Correggiari, 2000) indicates that the local sea-level lowstand closely matches the inferred global (eustatic) lowstand of $\sim 125 \mathrm{~m}$ below present sea level (Fleming et al., 1998), which would imply that net subsidence in the area North of the MAD has been negligible. In the absence of detailed information on subsidence patterns of the northern Adriatic shelf, we decided to adopt the uncorrected eustatic sea-level curve as a proxy of relative sea-level history. The corresponding transgression scenario was compared to an extensive set of radiocarbon datings of backbarrier peat (Correggiari et al., 1996a;

234 Trincardi and Argnani, 2001, ISMAR, unpublished data) to examine the validity of 235 this assumption (see below).

\subsection{Palaeo-tidal regime}

The northern Adriatic is presently characterized by a micro-tidal regime. The lunar semidiurnal M2 tidal amplitude increases from south to North due to a decrease in water depth. Offshore of Venice, the M2 tidal range is about $0.2 \mathrm{~m}$. Locally, tidal ranges may be up to $1 \mathrm{~m}$ due to resonance effects in embayments, for instance near Trieste (Bondesan et al., 1995). Although several models were developed to simulate present-day tidal dynamics in the Adriatic (Malačič et al., 2000; Cushman-Roisin and Naimie, 2002) little is known about palaeo-tidal regimes. Of particular interest in the context of this study is whether the elongate land-locked Adriatic basin may have exhibited transient tidal-resonance effects during the post-glacial sea-level rise, which caused the basin to widen and changed its shape (Cattaneo and Trincardi, 1999). If so,

To test this hypothesis, we developed a simple idealized 1-D model for tidal motion, 252 in which the Adriatic Sea was assumed an elongated box and cross-sectional 253 variations in water depth were neglected. The present bathymetry of the northern shelf 254 was used to derive an approximation of the initial (lowstand) topography in the form 255 of a series of line segments (Fig. 4). This profile represents the water depth along the 
256 axis of the basin. In order to properly approximate the basin in 1-D, a transversally

257 averaged effective depth has been used, biased towards the (deeper) parts with higher

258 velocities. The effective water depth $D$ was defined by multiplication of the maximum

259 depth along the central axis by 0.85 . In the analytical model, the influence of the

260 Earth's rotation is not taken into account and friction is neglected, which implies that

261 no damping occurs. Because the amplitude of the tidal motion is small and the

262 wavelength is large relative to $D$, the 1-D linearized shallow-water equations have

263 been used:

$\frac{\partial \zeta}{\partial t}+\frac{\partial}{\partial x}[D(x) u]=0$

266

$267 \quad \frac{\partial u}{\partial t}=-g \frac{\partial \zeta}{\partial x}$

268 where:

269

270

$\zeta=\zeta_{e}(t)$ at the open (southern) boundary

$271 \zeta, u<\infty$ at the closed (northern) boundary

272

273 In the above equations, $D(x)$ is the longitudinal depth profile in $\mathrm{km}$ and $g$ is the

274 gravitational acceleration in $\mathrm{m}^{2} / \mathrm{s}$. The $x$-coordinate runs northward along the central

275 axis of the basin. The variable $\zeta$ denotes the water-level elevation $(\mathrm{m})$ relative to the

276 water-level elevation at rest, and $u$ is the averaged velocity $(\mathrm{m} / \mathrm{s})$ in northward

277 direction. Water-level elevation is prescribed to be $\zeta_{e}=\alpha_{\mathrm{e}} \cos (\omega \mathrm{t})$ at the open

278 (southern) boundary. The angular forcing frequency for the M2 semidiurnal tidal

279 component is $\omega_{\mathrm{M} 2}=2 \pi / 44700=1.4 \cdot 10^{-4} \mathrm{rad} / \mathrm{s}$ and the present tidal amplitude at the

280 connection between the Adriatic and the Mediterranean Sea is $\omega_{\mathrm{e}, \mathrm{M} 2}=0.08 \mathrm{~m}$. For the

$281 \mathrm{~K} 1$ diurnal tidal component these numbers are $\omega_{\mathrm{K} 1}=2 \pi / 86162=7.3 \cdot 10^{-4} \mathrm{rad} / \mathrm{s}$ and

$282 \omega_{\mathrm{e}, \mathrm{K} 1}=0.04 \mathrm{~m}$, respectively. Palaeo-tidal responses at various sea levels have been

283 computed for the same forcing conditions.

285 The tidal amplitudes are shown as a function of coastline position $x$ for different Late

286 Quaternary sea levels (Fig. 5). The length of the basin increased over time as sea level

287 rose. The results for the present-day situation correspond well with the observations 
reported by Polli (1960). For the K1 tidal component, the fit depends significantly on the depth-correction factor of 0.85 , whereas the results for the M2 tidal component are relatively insensitive to this correction. Modelling results show that amplification of the M2 tidal component was most pronounced at $x=317 \mathrm{~km}$, where at present the water depth is $75 \mathrm{~m}$ along the central axis. Because damping due to friction for example is not included in this simple model, the resonance leads to a singular response in that situation. In reality, radiation of energy into the Mediterranean Sea is expected to keep amplification within reasonable bounds. On the other hand, amplification of the K1 tidal component increases with rising sea level. Although the exact tidal ranges are speculative, due to limitations of the model and uncertainties in boundary conditions, the modelling results clearly suggest that the older of the two barrier-lagoon systems was tidally influenced. Hence, cores and seismic profiles of backbarrier deposits may show remnants of tidal flats and channels. The tidal range decreased rapidly during subsequent sea-level rise, which indicates that tidally influenced transgressive deposits are much less likely to occur at shallower depths.

\subsection{Palaeo-wave climate}

Two major storm fields force the wave field in the Adriatic: the Bora and the Sirocco. During Bora storms, the wind is blowing from the northeast whereas Sirocco storms are characterized by steady winds from the southeast (Decouttere et al., 1998). The shape of the wave spectrum depends on the fetch length and the duration of the storm. Sirocco winds typically blow along the axis of the Adriatic Sea for several days and cause high swell waves in the northern part of the basin. In addition, the surge that accompanies a storm with a ten-year recurrence interval elevates average sea level in the Northern Adriatic by more than $1 \mathrm{~m}$ (Yu et al., 1998). The waves generated during a Sirocco event (large fetch and associated surge) are expected to be the most effective for reworking of shallow-marine sediments.

As the shallow northern Adriatic shelf flooded during the Late-Quaternary sea-level rise, its area increased sevenfold and the fetch increased significantly. The fetch increase is especially relevant for Sirocco events, during which the wind direction is parallel to the elongation of the basin. Significant wave height and period 
corresponding to a given fetch have been calculated using equations for fetch-limited conditions (Corps of Engineers, 1984):

$H_{s}=5.112 \cdot 10^{-4} U_{a} \sqrt{f}$

$$
T_{m}=6.238 \cdot 10^{-2} \sqrt[3]{U_{a} f}
$$

where $H_{s}$ is the significant wave height (m), $f$ is the fetch (m) and $T_{m}$ is the period (s) of the peak of the wave spectrum. $U_{a}$ is adjusted wind speed $(\mathrm{m} / \mathrm{s})$, given by:

$$
U_{a}=0.71 U^{1.23},
$$

where $U$ is the wind speed at $10 \mathrm{~m}$ above the water surface. The direction of wave propagation is set equal to the wind direction (cf. Slingerland and Keen, 1999). In this case, wind direction is $300^{\circ}$, which would represent a Sirocco event.

Based on the calculations, fetch increase between the LGM and present caused an increase of significant wave height and period by $20 \%$ and $15 \%$, respectively. As the northern Adriatic shelf has a relatively uniform slope, wave propagation during the late Quaternary is unlikely to have changed much since the LGM. However, possible changes in wind regime due to late Pleistocene climate changes are not included in these equations.

\subsection{Palaeo-circulation pattern}

The present-day surface circulation pattern of the northern Adriatic Sea consists of a large-scale counter clockwise baroclinic geostrophic structure with cyclonic gyres of thermohaline origin (Malanotte-Rizzoli and Bergamasco, 1983; Orlic et al., 1992; Artegiani et al, 1997). As a result of this counter clockwise circulation, a fine-grained sediment wedge (Fig. 1) is formed that consists of Po and the Apennine derived sediments that are dispersed southward and deposited in a narrow band along the Italian coast down to the Gulf of Manfredonia, in the area south of the Gargano promontory (Cattaneo et al., 2003). Analysis of high-resolution seismic data combined with radiocarbon datings from numerous cores indicate that the 
354 transgressive portion of the sediment wedge is 40 to $50 \mathrm{~km}$ wide and up to $25 \mathrm{~m}$ thick.

355 The transgressive deposits have been subdivided into three intervals of which the 356 lowest (pre $15 \mathrm{ka} \mathrm{BP}$ ) shows a patchy distribution of sediment depocenters, whereas

357 the middle and upper units display a dominant alongshore trend similar to the modern

358 sea-level highstand deposits (Cattaneo and Trincardi, 1999; Cattaneo et al., 2003).

359 The architecture of the middle unit (deposited between 14.8 and $11.3 \mathrm{cal}$ ka BP)

360 reflects a transitional period in which the modern oceanographic circulation pattern

361 was established. Hence, it appears from the stratigraphic data that the counter

362 clockwise current was initiated $\sim 15 \mathrm{ka} \mathrm{BP}$, most likely as a result of the increase in

363 basin size due to sea-level rise (Cattaneo and Trincardi, 1999).

364

365

366

367

368

369

370

371

372

373

374

375

376

377

378

379

380

381

382

383

384

385

386

387

\subsection{Palaeo-environmental synthesis}

A summary of the reconstruction of palaeo tides, wave climate, and rate of sea-level change is given in Figure 5a-c, which shows the various controlling factors as function of coastline position along a profile of the Northern Adriatic shelf from the MAD to Venice. The tidal amplitude derived from the analytical model reached a maximum during the early phase of transgression, when the coastline was located close to the edge of the MAD. The amplitude decreased gradually until it reached its present value at around $11 \mathrm{ka} \mathrm{BP}$. The wave climate gradually changed as sea level rose. Rates of sea-level rise varied greatly, with two distinct peaks corresponding to melt-water pulses 1A and 1B (Fairbanks, 1989).

The eustatic sea-level curve (Fig. 3) was combined with the present-day bathymetry of the Northern Adriatic shelf along the profile (Fig. 5d) to reconstruct palaeocoastline positions during transgression (Fig. 5e). Coastline position has been plotted together with the available radiocarbon dates of backbarrier deposits at the appropriate water depths. All radiocarbon datings cluster about the curve of palaeoshoreline position. Modest deviations from the profile can be observed, which reflect uncertainties in palaeo-water depths of the samples from which the radiocarbon datings were obtained, in conjunction with uncertainties in radiocarbon ages, and local topographic variability, as not all samples are located on the profile (Fig. 2). The data appear to be fully consistent with the reconstructed shoreline evolution, which justifies our assumption that net subsidence along the profile can be considered negligible (provided the sea-level curve is correct). Although the melt-water pulses 
only represent $3 \%$ of the time span for the Late-Quaternary sea level rise, their effect is very significant as an estimated $36 \%$ of the northern Adriatic shelf will be affected by these extremely rapid sea-level rises, owing to its low gradient (Fig. 5d).

The radiocarbon datings show that both studied isolated sediment bodies were deposited while the oceanic counter clockwise circulation was already active. This implies that during formation of the barrier-lagoon systems, most of the suspended fluvial sediment supplied to the northern Adriatic coastline was being removed by longshore currents to be redeposited at the south-western part of the inner shelf, with the possible exception of the coarsest fraction, which would have remained behind as a lag deposit.

\section{Sedimentological interpretation}

\subsection{Site A: deep barrier-lagoon system}

The shelf of the Northern Adriatic Sea between 100 and 80 m water depth is characterized by a relatively high gradient and is dissected by meandering channels (with lateral accretion surfaces), which are up to $20 \mathrm{~km}$ long and between 4 and $15 \mathrm{~m}$ deep. The orientation of the channels is predominantly North-South. Shallow seismic profiles (Cattaneo et al., 2001) show a laterally persistent peat layer that rests conformably on the pre-transgressive deposits (Fig. 6). Some channels incise below the peat layer (seismic profile II), whereas the bases of other channels coincide with the peat layer (seismic profile I). Not all channels can be clearly tied to the relative sea-level curve. Lateral-migration features, which are typical for tidal channels (see for example seismic profile II), are not present in channels assumed to have originated during a phase of incision associated with sea-level fall or lowstand conditions (Trincardi et al., 1996). The seismic profiles also suggest that most of the channels are not filled with sediment. An exception to this is a narrow $(<500 \mathrm{~m})$ incised distributary channel of more than $15 \mathrm{~m}$ deep that is completely filled transgressive deposits and which presently has no morphological expression (seismic profile IV).

The heterolithic infilling of the channel (Fig. 6; seismic profile IV) suggests that tidal deposition may have played an important role during this phase of the transgression. The tidal amplification inferred from modelling for this time interval (Fig. 5a) would 
provide a potential scenario for an estuarine infill of this distributary channel. As sea

423 level rose at a rate of more than $60 \mathrm{~mm} / \mathrm{a}$ (Fig. 3 and Fig. 5), the distributary channel

424 became an estuary and was filled with centimetre to millimetre-scale alternating silt

425 and clay deposits from both marine and fluvial in origin. It is uncertain whether this

426 channel was a distributary of the palaeo-Po or of a local river or possibly even a tidal

427 channel. In the latter case there would have been no local fluvial sediment source to

428 fill the channel and all the sediment must have been marine in origin. Seismic profile

429 IV shows that the top of the channel infill is formed by a wave-ravinement surface

430 (Fig. 6).

431

432 A thin peat layer on top of older, pre-transgressive sands forms the base of the

433 backbarrier deposits. Its presence demonstrates that some backbarrier areas were

434 sheltered from sediment input (Fig. 6, seismic profile II). The peat layer is covered by

435 a 1 to $3 \mathrm{~m}$ thick coarsening-upward sequence characteristically associated with a

436 transgressive backbarrier setting, suggesting that barrier islands were present during

437 this phase of rapid sea-level rise. The inferred age of the peat layer in core AN97-31

438 (14.3 ka BP; Cattaneo et al., 2001; ISMAR, unpublished data) matches the

439 reconstructed shoreline position at that time (Fig. 5). Two intervals consisting of lag

440 deposits with an erosional base overly the backbarrier deposits. The mollusc

441 assemblage on top of the lower erosion surface (Fig. 6; core AN97-31) is

442 characterized by shallow-marine species, intermixed with some brackish and open-

443 marine species (Cattaneo et al., 2001). The mollusc assemblage directly above the

444 upper erosion surface comprises predominantly open-marine species. The presence of

445 two superimposed erosion surfaces with shell lags of different palaeo-environmental

446 significance suggests that the first is associated with incision by a tidal channel (i.e., a

447 tidal ravinement surface). The second surface most likely represents a wave-

448 ravinement surface as it separates shoreface sediments from backbarrier deposits

449 (Cattaneo et al., 2001).

450

4.2. Site B: shallow barrier-lagoon system

452

453 A narrow elongated sand ridge at the 42-m isobath southeast of the modern Po delta

454 can be traced for about $50 \mathrm{~km}$ along the palaeo-coast line (Fig. 2). Radiocarbon dating

455 of a peat layer at the base of the sand ridge indicates an age of $10.5 \mathrm{ka} \mathrm{BP}$ 
456 (Correggiari et al., 1996a) which agrees with the reconstructed coastline position (Fig.

457 5). The morphological expression of the sand ridge strongly suggests that it is a

458 drowned barrier island (Fig. 2). Sediment cores (Fig. 8) from the sand ridge show a

459 coarsening-upward trend indicative of a barrier environment. Section V (Fig. 8)

460 shows that the sand ridge dips slightly towards the south. Overall the ridges are

461 between 2 and 3 meter thick. Two ravinement surfaces are recognised in the cores

462 (Fig. 8). The upper ravinement surface (Rs) originates from wave reworking during

463 transgression. The lower ravinement surface (tRs) most likely is caused by migrating

464 tidal channels (Cattaneo and Steel, 2003). Morphologically, the drowned barrier-

465 lagoon system shows similarities to the modern Venice lagoon with its narrow barrier

466 islands and extensive backbarrier area. There is no evidence of a preserved tidal delta.

467 Petrographic composition of the barrier sands indicates a Po-type source (Colantoni et

468 al., 1990).

469

470 The overstepped barrier chain rests on a $25 \mathrm{~km}$ wide sub-horizontal platform. Seismic

471 profiles (IDROSER, 1985, 1990) show that small channels filled with sediments of

472 pre-transgressive age dominate the platform subsurface (Fig. 9). The abundant

473 channel fills, 2 to $5 \mathrm{~m}$ deep and 100 to $300 \mathrm{~m}$ wide, are all present at the same

474 stratigraphic level. Lateral channel migration is indicated by steeply dipping reflectors

475 (both East and Westward), which represent point bars that are up to $300 \mathrm{~m}$ wide (Fig.

476 9). Locally, channel density is up to four channels per kilometre. The seismic data

477 suggest that the platform may have originated as part of a low-gradient Pleistocene

478 alluvial (braid) plain, but no core data are available to confirm this. The platform is

479 bounded to the East by a steep, $5 \mathrm{~m}$ high escarpment that resembles the confinement

480 of an older river terrace.

481

$482 \quad$ 5. Grain-size analysis

483

484

\subsection{Data and results}

485

486 Seven cores (three from the deep barrier-lagoon system at Site A, three from the

487 shallow system at Site B, and one from relict transgressive deposits in 24 m water

488 depth (Correggiari et al., 1996a) were sampled for grain-size analysis (Fig. 10). All

489 grain-size measurements were made with a laser-diffraction spectrophotometer 
490 (Konert and Vandenberghe 1997). All cores show typical transgressive backbarrier

491 sequences overlying pre-transgressive sediments. The pre-transgressive sediments are

492 conformably overlain by a $\sim 30 \mathrm{~cm}$ thick bed comprised of mud, organic-rich mud and

493 peat (Fig. 10). This bed is followed by an upward-coarsening backbarrier sequence of

494 variable thickness, which is bounded at the top by an erosional surface. This erosion

495 surface represents the wave-ravinement surface.

496

497 The grain-size distributions of the backbarrier deposits below the wave-ravinement

498 surface may be interpreted as mixtures of distinct end-member grain-size populations

499 (Fig. 10), which appear to be fixed (cf. Weltje and Prins, 2003). Within each core, the

500 relative abundances of these grain-size populations define overall coarsening-upward

501 trends. These trends reflect the change from a distal to a more proximal backbarrier

502 depositional environment which consistent with a transgressive barrier which in our

503 case is evolves overstepped.

504

505 According to Friedman (1961) characteristics of the grain size distribution (c.f. mean

506 grain size and skewness) can be used to identify sediments that have been transported

507 under different energy regimes and transport conditions. Figure 11 shows cross-plots

508 of skewness and mean grain size for three different facies (sandy shoreface deposits,

509 silty-sandy backbarrier deposits and clayey backbarrier deposits). The cross plot for

510 the clayey backbarrier deposits (Fig. 11A) appears to be uncorrelated, which is not

511 surprising as these deposits result from suspension fallout in a relatively quiet

512 environment. The cross plot of the silty to sandy backbarrier deposits (Fig. 11B)

513 shows a clear relation between mean grain size and skewness. Inspection of the grain-

514 size distributions (Fig. 10) reveals that this correlation arises from the mixing of silt

515 and very-fine sand sized populations. This mixing pattern is inferred to reflect several

516 factors: (1) distance from the barrier island, which acted as the local sand source; (2)

517 variability of energy conditions, i.e. fair weather vs. storms (and associated washover

518 deposits), to which the backbarrier is especially sensitive; (3) relative importance of

519 tidal deposition. Samples from the sandy shoreface above the transgressive

520 ravinement surface (Fig. 11C) display similar phenomena.

522 Overall, the sandy backbarrier and shoreface samples (Fig. 11B and C) show a

523 relation between mean grain size and water depth, where the fine grained samples 
524 come from the deep water cores while the coarse samples are retrieved from the

525 shallow water cores. This implies that shallow-water shoreface sands are on average

526 coarser-grained than shoreface sands from deeper water (with the exception of

527 samples from core AR 00-45).

528

529

\subsection{Interpretation}

530

531 Our palaeo-environmental reconstruction indicates that the barrier-lagoon systems

532 developed when the counter-clockwise circulation pattern was already well

533 established (Trincardi et al., 1996). This implies that the suspended sediment load

534 from the Po (the dominant sediment source) was effectively transported along the east

535 coast of the Adriatic Sea where it is deposited in the transgressive sediment wedge

536 (Fig. 1). It is uncertain how much sand was left behind near the river mouth which

537 would have been a potential sediment source for the barriers. Local transport

538 pathways for the river sand by longshore currents may different from the prevailing

539 oceanic currents. Furthermore, the position of the Po during the Late Quaternary is

540 still poorly known. It is uncertain whether the Po was located to the east or to the west

541 of the barrier-lagoon system. In view of these uncertainties, it is not possible to

542 reconstruct the sediment supply of the barrier-lagoon system from fluvial sources.

543 Nevertheless, cores and seismic profiles suggest that the amount of sand on the

544 Adriatic shelf is low. Between the preserved two barrier-lagoon system, the pre-

545 transgressive Pleistocene sediments not covered by transgressive sands which implies

546 that the supply of sand must have been limited or local. The shoreface sand source

547 therefore must be a mixture of fluvial ( $\mathrm{Po}$ ) origin and reworked Pleistocene substrate

548 sediments. If we consider the grain size of the Pleistocene substrate to have been

549 spatially homogeneous and the rate of sediment supply by longshore drift limited, we

550 may assume that the grain-size of the shoreface primarily reflects progressive sorting

551 by continuous reworking (Swift et al., 1991). Such conditions cause a progressive

552 coarsening of the shoreface, which represents a lag deposit, because fine-grained

553 sediment is moved to the backbarrier area and carried offshore. The latter will be

554 transported along with the prevailing oceanic currents to the transgressive sediment

555 wedge. This suggests that the amount of time available for reworking may be

556 mirrored in the grain size of the shoreface deposits (Guillén and Hoekstra,1996). Yet,

557 this is largely dependent on both the grain-size and amount of sediment supplied in 
558 time by both fluvial and substrate sources. Figures $12 \mathrm{~A}$ and B show that there is no

559 relation between the rate of sea level rise, which is a function of reworking time, and

560 the grain size of the backbarrier deposits. Nor is there a relation between tidal

561 amplitude, wave climate and the grain size of the backbarrier deposits (not shown

562 here). This suggests that tidal deposition and washover are not significantly

563 influenced by the rate of sea level rise. However, Figure $12 \mathrm{C}$ shows an overall

564 negative correlation between the grain size of the shoreface sands and the rate of sea-

565 level rise.

566

567

568

569

570

571

572

573

574

575

576

577

578

579

580

581

582

583

584

585

586

587

588

589

590

591

\section{Effects of tides and waves}

\subsection{BarSim model}

An adapted version of the numerical model BarSim (Storms et al., 2002; Storms, 2003; Storms and Swift, 2003) was used to evaluate the effects of tidal and washover on coastal deposition during a sea level rise. In contrast to other cross-shore models (e.g. Cowell et al., et al., 1999) BarSim is not constrained by the Bruun rule (Bruun, 1962) or other geometric rules (Stive and De Vriend., 1995). It has a dynamic equilibrium shoreface gradient that relates to changes in erosion and deposition at the shoreface as a function of wave characteristics and sediment supply. BarSim simulates coastal evolution in cross-section, based on rules for sediment resuspension and deposition at the shoreface, as well as backbarrier deposition (Fig. 13). Previous applications of the model have shown that BarSim is capable of reproducing the morphological evolution and stratigraphic record associated with retrogradational, aggradational and progradational wave-dominated shorelines. As the model has been described in detail in previous publications, we will restrict the discussion to the implementation of tidal deposition into BarSim.

BarSim simulates different depositional patterns for storm and fair-weather conditions. Storm conditions, defined by waves exceeding a critical height, last for short periods only, during which washover and shoreface deposition are dominant (Storms, 2003). Fair-weather conditions between successive storms, as modelled by BarSim, can last for several years. Over such long periods, tidal deposition may have 
592 a significant influence on backbarrier deposition, for instance by decreasing

593 backbarrier accommodation.

594

595 The rate of tidal deposition is a function of tidal amplitude, tidal prism, tidal basin

596 area, rate of sediment supply, and sediment grain size (Van Goor et al., 2003; Chang

597 et al., 2006). In view of the uncertainties associated with each of these factors on

598 geological time scales, we did not attempt to simulate the full complexity of tidal

599 deposition, but restricted ourselves to capturing its essential effects on backbarrier

600 accommodation. In BarSim, the rate of tidal deposition is modelled as a linear

601 function of tidal prism (tidal amplitude $\times$ basin width). In the absence of washover

602 processes during fair weather conditions, all sediment resuspended from the shoreface

603 by fair-weather waves is potentially available for tidal deposition. The grain-size

604 distribution of sediments available for tidal deposition is different from the grain-size

605 distribution of the resuspended shoreface sediment. In BarSim, it is assumed that

606 deposition of the sand fraction is limited to the tidal channel, and tidal-flat deposits

607 are much finer grained. Therefore, we assumed as a first estimate that $30 \%$ of the sand

608 which is available at the shoreface will can be transported to the backbarrier area

609 based on an evaluation of the overall simulated backbarrier fill grain-size distribution.

610 This number will depend on local conditions, but at present no data exists to tune this

611 variable to real-world examples of tidal deposition.

612

613 Since BarSim is a 2D model that simulates cross-shore barrier behaviour, the cross-

614 shore profile should be interpreted as averaged over one coastal cell, thereby

615 including both the shoreface and the tidal deltas areas. Most of the sand transported

616 by the tidal simulation will therefore in reality end up as tidal deltas.

617

618 The upper limit on tidal deposition is determined by the backbarrier accommodation.

619 In case the amount of sediment available for tidal deposition exceeds backbarrier

620 accommodation, the remaining sediment will be redeposited at the shoreface. An

621 increase in accommodation of the tidal basin under conditions of persistent sea-level

622 rise may lead to a situation in which the increase in accommodation of the tidal basin

623 cannot be balanced by sediment supply, which results in a gradual deepening of the

624 tidal basin, and eventual drowning of the barrier-lagoon system (Storms and Swift,

625 2003; Van Goor et al., 2003). As an example of a BarSim run, Figure 14 shows the 
626 simulated coastal response to a rising sea level across an antecedent topography that

627 resembles the Northern Adriatic near site B. Due to the rapid increase of backbarrier

628 accommodation, the simulated barrier cannot retrograde and is drowned. The

629 sensitivity of this mechanism for wave-dominated and tide-dominated environments

630 is further explained below.

631

632

633

6.2. BarSim simulations in tide- and wave-dominated conditions

634

635 To illustrate the generic behaviour of transgressive barrier-lagoon systems, we

636 defined two scenarios which represent tide- and wave-dominated conditions,

637 respectively. Both scenarios comprise 5000 years of transgression while sea level

638 rises $20 \mathrm{~m}$ at a constant rate (Fig. 15). No extra sediment is added to the simulated

639 system by longshore drift, nor is any sediment deposited by suspension fallout. In

640 Scenario 1, the wave-dominated case, tidal amplitude is zero and transgression occurs

641 by washover deposition exclusively. In Scenario 2, we added a macro-tidal regime

642 (tidal amplitude $=3 \mathrm{~m}$ ). The modelling results show that rates of transgression are

643 comparable in both scenarios. However, it is apparent from Figure 15 that filling of

644 the backbarrier with predominantly fine-grained sediments is, as expected, much more

645 effective under macro-tidal conditions. The fine-grained sediments are trapped in the

646 backbarrier, implying that erosion at the shoreface is more extensive for Scenario 2

647 than for Scenario 1, in accordance with the closed sediment budget in both scenarios.

648 In Scenario 1, the depth and width of the backbarrier area increase, while the width of

649 the barrier island decreases over time, which will eventually result in a barrier-island

650 overstep similar to Figure 14 (Storms and Swift, 2003). A barrier-island overstep is

651 unlikely to occur in Scenario 2. In this scenario, the width of the tidal basin also

652 increases, but the increase in backbarrier accommodation is accompanied by an

653 increase in the tidal prism, which in turn promotes import of sediment into the tidal

654 basin. Hence, backbarrier deposition is much more likely to keep pace with the

655 increasing backbarrier width.

656

657

6.3. Implications for the Adriatic barrier-lagoon systems

658 
659 The modelling results indicate that the probability of a drowned barrier-lagoon system

660 is inversely proportional to tidal amplitude under conditions of moderate sea-level

661 rise, if all other factors are assumed equal. However, under conditions of prolonged

662 extremely rapid sea-level rise, no barrier-lagoon system is indefinitely stable (Storms

663 and Swift, 2003). Hence, under extreme conditions, it is to be expected that even tide-

664 dominated barrier-lagoon systems can be overstepped. The deep isolated sediment

665 body (Site A) appears to be a case in point. It formed during a period of significant

666 tidal amplification, as indicated by the palaeo-tidal reconstruction. According to the

667 BarSim results, this may have prevented it from being overstepped, unless sea-level

668 rise was extremely rapid. The preserved stratigraphic successions at Site A strongly

669 suggest that a barrier-island overstep did occur in the course of melt water pulse 1A.

670 Thus the inferred rate of sea-level rise during that period ( $\sim 60 \mathrm{~mm} / \mathrm{a})$ would have

671 been too high for the system to maintain a dynamic equilibrium. The high rate of sea-

672 level rise also explains why the system was partially preserved, because it limited the

673 time available for wave-reworking of the drowned barrier-lagoon deposits.

674

675 The shallow isolated sediment body at Site B represents an overstepped barrier island

676 in a wave-dominated regime (Fig. 5). The rate of sea level rise at the time of overstep

677 was relatively low ( $\sim 10 \mathrm{~mm} / \mathrm{a})$, but still much higher than present-day values. The

678 simulations shown in Fig. 15 illustrate transgression over a planar substrate. In case of

679 the overstepped barrier island in the Adriatic Sea, a low gradient Pleistocene plateau

680 was positioned landward of the island (Fig. 2). Backbarrier accommodation increased

681 abruptly when sea level rose above the elevation of the plateau. The presence of

682 relatively large tidal inlet-like depressions between the islands (Fig. 2) is consistent

683 with the abrupt increase in backbarrier area. The absence of significant backbarrier

684 deposits seems to indicate that tidal deposition could not compensate the abrupt

685 increase in backbarrier accommodation (Fig. 14). Barrier-island overstep at Site B

686 was therefore most likely controlled by antecedent topography.

687

688 It is not clear why the barrier-lagoon system at Site B was so well preserved, because

689 the relatively low rate of sea-level rise would have allowed sufficient time for

690 reworking of the drowned barrier-lagoon system by wave activity. A possible

691 explanation may be sought in the uncertainties surrounding our reconstructions of

692 wave climate and local rates of sea-level rise, which controlled the preservation 
693 potential of the drowned barrier-lagoon system. However, other research shows

694 similar preservation potential for drowned barrier-lagoon systems (Gardner et al.,

695 2005; Gardner et al., 2007).

696

697

\section{7. Conclusions}

699

700 In our analysis of two preserved isolated sediment bodies on the Northern Adriatic

701 shelf, interpreted as barrier-lagoon systems, we combined reconstructions of

702 palaeoceanographic conditions and process-response simulations with analysis of

703 sedimentological, stratigraphic and seismic data. This multidisciplinary approach has

704 provided new insights into the formation and preservation of barrier-lagoon systems

705 during rapid sea-level rise. Our reconstructions of sea-level rise, tidal regime and

706 wave climate in the time interval between $15 \mathrm{ka} \mathrm{BP}$ and $8 \mathrm{ka} \mathrm{BP}$ indicated that the

707 conditions under which the two barrier-lagoon systems evolved were remarkably

708 different. The oldest system, present at Site A (80-90 m below present water depth),

709 formed under conditions of very rapid sea-level rise $(60 \mathrm{~mm} / \mathrm{a})$, with tidal amplitude

710 of about $1.1 \mathrm{~m}$, and waves that were about $15 \%$ lower than they are at present. Sea

711 level rose at about $10 \mathrm{~mm} / \mathrm{a}$ during formation of the youngest system, at Site B (42 m

712 below present water depth), whereas the tidal amplitude was about the same as today

$713(\sim 0.5 \mathrm{~m})$, and wave activity was only fractionally $(5 \%)$ less.

714

715 The BarSim simulations reveal that the probability of barrier-island overstepping

716 during transgression is inversely proportional to tidal amplitude, if all other factors are

717 assumed equal. Overstepping in the absence of tides is primarily caused by the fact

718 that washover is the only mechanism by which sediment can be supplied to the

719 backbarrier area. Under micro-tidal conditions, the increase in backbarrier

720 accommodation during rapid sea-level rise cannot be compensated and the backbarrier

721 deepens, leaving the barrier island isolated from the mainland. Tidal deposition

722 greatly increases the rate at which backbarrier accommodation can be filled, which

723 implies that barrier-lagoon systems under macro-tidal conditions can remain in

724 equilibrium at higher rates of sea-level rise than systems under micro tidal conditions. 
726 The drowned barrier chain at Site B is separated from the palaeo-shoreline by a wide

727 backbarrier. The presence of an overstepped barrier-island chain at the edge of a sub-

728 horizontal plateau clearly demonstrates the overriding importance of antecedent

729 topography on the evolution of barrier-lagoon systems. Drowning of this system

730 appears to have been caused by the abrupt increase of backbarrier accommodation

731 during transgression. It is not clear, however, why the system at Site B was not

732 completely reworked, contrary to expectations based on the modest rate of sea-level

733 rise in conjunction with the local presence of a relict sub-horizontal alluvial plain,

734 which would imply that the overstepped barrier must have remained within reach of

735 wave erosion for a considerable amount of time. The barrier-lagoon system at Site A

736 does not show clear morphological evidence of overstepping. Remnants of the deep

737 barrier system are preserved in a series of pre-existent channels dating back to a sea-

738 level lowstand, some of which were filled with heterolithic deposits. Other channels,

739 which appear to have formed during sea-level rise, are not filled at all. The barrier-

740 lagoon system at Site A developed under conditions of large tidal amplitude, which

741 permitted rapid transgression due to effective filling of backbarrier accommodation.

742 However, this system apparently failed to keep up with the anomalously high rate of

743 sea-level rise resulting from melt-water pulse 1A. Its preservation is thus easily

744 explained, contrary to that of the barrier-lagoon system at Site B.

746 The grain-size analysis of locally preserved shoreface deposits across the Northern

747 Adriatic shelf indicates a signature of progressive sorting related to the amount of

748 time available for wave reworking, although the timescale associated with this

749 phenomenon could not be established in the absence of information on the

750 contribution of material derived from substrate erosion.

\section{Acknowledgements}

This study was carried out with financial support from the European Union

756 (EUROSTRATAFORM research programme, contract no. EVK3-CT-2002-00079).

757 We are grateful to Richard Signell and Klaas Scholte, for processing the bathymetric

758 data of the Adriatic Sea, and to Albert Kettner for a preprint of his paper and

759 providing Figure 1. ISMAR (CNR) contribution n.XXXX. 


\section{References}

763

764

765

766

767

768

769

770

771

772

773

774

775

776

777

778

779

780

781

782

783

784

785

786

787

788

789

790

791

792

793

794

795

796

797

798

799

800

801

802

803

804

805

806
Amorosi, A., Colalongo, M. L., Fusco, F., Pasini, G., Fiorini, F., 1999. Glacio-eustatic Control of Continental-Shallow Marine Cyclicity from Late Quaternary Deposits of the southeastern Po Plain, Northern Italy. Quaternary Research 52,1-13.

Amorosi, A., Centineo, M.C., Colalongo, M.L., Pasini, G., Sarti, G.,Vaiani, S.C., 2003. Facies architecture and latest-Pleistocene-Holocene depositional history of the Po delta (Comacchio area), Italy. Journal of Geology 111, 39-56.

Argnani, A., Artoni, A., Ori, G.G., Roveri, M., 1991. L'avanfossa centro-Adriatica: stili strutturali e sedimentazione. St. Geol. Camerti, Vol. Spec.1, 371-381.

Artegiani, A., Bregant, D., Paschini, E., Pinardi, N., Raicich, F., Russo, A., 1997. The Adriatic Sea general circulation, part II: Baroclinic circulation structure. J. Phys. Oceanogr. 27, 1515-1532.

Bard, E., Hamelin, B., Arnold, M., Montaggioni, L., Cabioch, G., Faure, G., Rougerie, F., 1996. Deglacial sea-level record from Tahiti corals and the timing of global meltwater discharge. Nature 382, 241-244.

Belknap, D.F., Kraft, J.C., 1981. Preservation potential of transgressive coastal lithosomes on the U.S. Atlantic shelf. Marine Geology 42, 429-442.

Bondesan, M., Favero, V., Vinals, M.J., 1995. New evidence on the evolution of the Po-delta coastal plain during the Holocene. Quaternary International 29/30, 105-110.

Brunetti, A., Denèfle, M., Fontugne, M., Hatté, C., Pirazzoli, P.A., 1998. Sea-level and subsidence data from a Late Holocene backbarrier lagoon (Valle Standiana, Ravenna, Italy). Mar. Geol. 150, 29-37.

Carminati, E., Di Donato, G., 1999. Separating natural and anthropogenic vertical movements in fast subsiding areas: the Po plain (N. Italy) case. Geophys. Res. Lett. 26, 2291-2294.

Cattaneo, A. Trincardi, F., 1999. The Late-Quaternary transgressive record in the Adriatic epicontinental sea: basin widening and facies partitioning. In: Bergman, K.M., Snedden, J.W. (Eds.) Isolated Shallow Marine Sand Bodies: Sequence Stratigraphic Analysis and Sedimentologic Interpretation. SEPM Special Publication 64, 127-146.

Cattaneo, A., Correggiari, A., Taviani, M. and Trincardi, F. (2001) Sedimentologic expressions of the late-Quaternary ravinement surface in the Adriatic Sea, Italy. Int. Assoc. Sedimentol. 21th Meeting, Davos, Switzerland. 
807 Cattaneo, A., Coreggiari, A. Langone, L. and Trincardi, F. (2003) The Late-Holocene

808 Gargano subaqeous delta, Adriatic shelf: Sediment pathways and supply fluctuations.

809 Marine Geology 193, 161-191.

810

811

812

813

814

815

816

817

818

819

820

821

822

823

824

825

826

827

828

829

830

831

832

833

834

835

836

837

838

839

840

841

842

843

844

845

846

847

848

849

850

851

852

853

854

Cattaneo, A., Steel, R.J., 2003. Transgressive deposits: an overview of their variability. Earth-Science Reviews 62, 187-228.

Chang, T.S., Bartholomä, A., Flemming, B.W., 2006. Seasonal dynamics of finegrained sediments in a backbarrier tidal basin of the German Wadden Sea (Southern North Sea). Journal of Coastal Research 22, 328-338.

Clark, P.U., Mitrovica, J.X., Milne, G.A., Tamisiea, M.E., 2002. Sea-Level fingerprinting as a direct test for the source of global meltwater pulse IA. Science 295, 2438-2441

Colantoni, P., Preti, M., Villani, B., 1990. Sistema deposizionale e linea di riva olocenica sommersi in Adriatico al largo di Ravenna. Giornale di Geologia 51, 1-18.

Corps of Engineers, 1984. Shore protection manual, 4th ed. Vicksburg, Mississippi Department of the Army, Waterways Experiment Station, Coastal Engineering Research Center, Wahington, D.C.

Correggiari, A., Field, M., Trincardi, F., 1996a. Late Quaternary transgressive large dunes on the sediment-starved Adriatic shelf. In: De Batist, M., Jacobs, P. (Eds.), Geology of Siliciclastic Shelf Seas, Geological Society, London, Special Publications 117, pp. 155-169.

Correggiari, A., Roveri, M., Trincardi, F., 1996b. Late Pleistocene and Holocene evolution of the North Adriatic sea. Il Quaternario 9, 697-704.

Cowell, P.J., Roy, P.S. Cleveringa, J. and de Boer, P.1., 1999. Simulating coastal systems tracts using the shoreface translation model. In: Harbaugh, J.W., Watney, W.L., Rankey, E.C., Slingerland, R., Goldstein, R.H., and Franseen, E.K. (Eds.), Numerical Experiments in Stratigraphy: Recent Advances in Stratigraphic and Sedimentologic Computer Simulations, Society of Economic Paleontologists and Mineralogists, Special Publication 42, 371-380.

Curray, J.R., 1964. Transgression and regression. In: Miller, R.L. (Ed.). Papers in Marine Geology: New York. The Macmillan Company, 175-203.

Cushman-Roisin, B., Naimie. C.E., 2002. A 3D finite-element model of the Adriatic tides. Journal of Marine Systems 37, 279-297.

Decouttere, C., De Backer, K., Monbaliu, J., Berlamont, J., 1998. Wave refraction in the upper Adriatic Sea. In: Gambolati G. (Ed.). CENAS. Coastline Evolution of the Upper Adriatic Sea due to Sea Level Rise and Natural and Anthropogenic Land Subsidence. Kluwer Academic Publishers, the Netherlands, 169-183. 
855 Fairbanks, R.G., 1989. A 17,000-year glacio-eustatic sea level record - influence of 856 glacial melting rates on the Younger Dryas event and deep-sea circulation, Nature 857 342, 637-642.

858

859

860

861

862

863

864

865

866

867

868

869

870

871

872

873

874

875

876

877

878

879

880

881

882

883

884

885

886

887

888

889

890

891

892

893

894

895

896

897

898

899

900

901

902

903

Fleming, K., Johnston, P., Zwartz, D., Yokoyama, Y., Lambeck, K., Chapell, J., 1998. Refining the eustatic sea level-curve since the Last Glacial Maximum using far- and intermediate-field sites. Earth and Planetary Science Letters 163, 327-342.

Forbes, D.L., Taylor, R.B., Orford, J.D., Carter, R.W.G., and Shaw, J., 1991. Gravel barrier migration and overstepping. Marine Geology 97, 305-313.

Friedman, G.M., 1961. Distinction between dune, beach and river sands from their textural characteristics. Journal of Sedimentart Petrology 31, 514-529.

Gardner, J.V., Dartnell, P., Mayer, L.A., Hughes Clarke, J.E., Calder, B.R., Duffy, G., 2005. Shelf-edge deltas and drowned barrier-island complexes on the northwest Florida outer continental shelf. Geomorphology 64, 133-166.

Gardner, J.V., Calder, B.R., Hughes Clarke, J.E., Mayer, L.A., Elston, G., Rzhanov, Y., 2007. Drowned shelf-edge deltas, barrier islands and related features along the outer continental shelf north of the head of De Soto Canyon, NE Gulf of Mexico. Geomorphology 89, 370-390.

Guillén, J., Hoekstra, P., 1996. The "equilibrium" distribution of grain size fractions and its implications for cross-shore sediment transport: a conceptual Model. Marine Geology 135, 15-33.

IDROSER, 1985. Ricerca di depositi sabbiosi sul fondo del Mare Adriatico da utilizzare per il ripascimento delle spiagge in erosione. Report Idroser S.p.A. Idrorisorse per lo sviluppo dell'Emilia-Romagna, Bologna 176 pp.

IDROSER, 1990. Ricerca di depositi sabbiosi sul fondo del Mare Adriatico da utilizzare per il ripascimento delle spiagge in erosione. 2a Campagna di ricerca. Report Idroser S.p.A. Idrorisorse per lo sviluppo dell'Emilia-Romagna, Bologna 115 pp.

Kent, D.V., Rio, D., Massari, F. Kukla, G. Lanci, L., 2002. Emergence of Venice during the Pleistocene. Quaternary Science Reviews 21, 1719-1727.

Kettner, A.J., Syvitski, J.P.M., 2007. Predicting Discharge and Sediment Flux of the Po River, Italy since the Late Glacial Maximum. IAS Special Issue (in press).

Konert, M., Vandenberghe, J., 1997. Comparison of laser grain size analysis with pipette and sieve analysis; a solution for the underestimation of the clay fraction. Sedimentology 44, 525-535.

Leatherman, S.P., 1983. Barrier island evolution in response to sea level rise: a discussion. Journal of Sedimentary Petrology 53, 1026-1031. 
912

913

914

915

916

917

918

919

920

921

922

923

924

925

926

927

928

929

930

931

932

933

934

935

936

937

938

939

940

941

942

943

944

945

946

947

948

949

950

951

952

953

Liu, J.P., Milliman, J.D., 2004. Reconsidering melt-water pulses 1A and 1B: global impacts of rapid sea-level rise. Journal of Ocean University of China 3, 183-190.

Malačič, V., Viezzoli, D., Cushman Roisin, B., 2000. Tidal dynamics in the northern Adriatic Sea. Journal of Geophysical Research 105(C11), 26,265-26,280.

Malanotte-Rizzoli, P., Bergamasco, A., 1983. The dynamics of the coastal region of the northern Adriatic Sea. J. Phys. Oceanogr. 13, 1105-1130.

Nummedal, D., Swift, D.J.P., 1987. Transgressive stratigraphy at sequence-bounding unconformities: some principles derived from Holocene and Cretaceous examples. In: Nummedal, D., Pilkery, O.H., Howard, J.D. (Eds.) Sea-level fluctuation and coastal evolution. SEPM special publication 41, 241-260.

Orlic, M., Gacic, M., La Violette, P.E., 1992. The currents and circulation of the Adriatic Sea. Oceanol. Acta 15, 109-124.

Rampino, M.R., and Sanders, J.E., 1980. Holocene transgression in south-central Long Island, New York. Journal of Sedimentary Petrology 50, 1063-1080.

Rampino, M.R., and Sanders, J.E., 1982. Holocene transgression in south-central Long Island, New York-reply. Journal of Sedimentary Petrology 53, 1020-1025.

Rampino, M.R., and Sanders, J.E., 1983. Barrier island evolution in response to sea level rise: reply. Journal of Sedimentary Petrology 53, 1031-1033.

Pieri, M., Groppi, G., 1981. Subsurface geological structure of the Po plain, Italy. In:Progetto Finalizzato Geodinamica. CNR Publ. 414, 13p.

Pirazzoli, P.A., 2005. A review of possible eustatic, isostatic and tectonic contributions in eight late-Holocene relative sea-level histories from the Mediterranean area. Quaternary Science Reviews 24, 1989-2001.

Polli, S., 1960. La propagazione delle maree nell'Adriatico. Atti del Convegno dell'Associazione Geofisica Italiana, Roma 1959, 11p.

Ridente, D., Trincardi, F. (2002) Eustatic and tectonic control on deposition and lateral variability of Quaternary regressive sequences in the Adriatic basin (Italy). Marine Geology 184, 273-293.

Ridente, D., Trincardi, F., 2006. Active foreland deformation evidenced by shallow folds and faults affecting late Quaternary shelf-slope deposits (Adriatic Sea, Italy). Basin Research 18, 171-188.

Slingerland, R., Keen, T.R., 1999. Sediment transport in the western interior seaway of North America: predictions from a climate-ocean-sediment model. In: Bergman, K.M. Snedden, J.W. (Eds.) Isolated Shallow Marine Sand Bodies: Sequence Stratigraphic Analysis and Sedimentologic Interpretation. SEPM Special Publication 64, 179-190. 
954 Stive, M.J.F. and De Vriend, 1995. Modelling shoreface profile evolution. Marine

955 Geology 126, 235-248.

956

957

958

959

960

961

962

963

964

965

966

967

968

969

970

971

972

973

974

975

976

977

978

979

980

981

982

983

984

985

986

987

988

989

990

991

992

993

994

995

996

997

998

999

1000

1001
Storms, J.E.A., 2003. Event-based stratigraphic simulation of wave-dominated shallow-marine environments. Marine Geology 199, 83-100.

Storms, J.E.A., Swift, D.J.P., 2003. Shallow marine sequences as the building blocks of stratigraphy: insights from numerical modelling. Basin Research 15, 287-303.

Storms, J.E.A., Weltje, G.J., Van Dijke, J.J., Geel, C.R., Kroonenberg, S.B., 2002. Process-response modeling of wave-dominated coastal systems: simulating evolution and stratigraphy on geological timescales. J. Sed. Res. 72, 226-239.

Swift, D.J.P., 1968. Coastal erosion and transgressive stratigraphy. Journal of Geology 76, 444-456.

Swift, D.J.P., Phillips, S., Thorne, J.A., 1991. Sedimentation on continental margins, IV: lithofacies and depositional systems. In: Swift. D.J.P., Oertel, G.F., R.W. Tillman, R.W., Thorne, J.A. (Eds.) Shelf Sand and Sandstone Bodies. International Association of Sedimentologists, Special Publication 14, 89-152.

Swift, D.J.P. and Moslow, T.F., 1982. Holocene transgression in south-central Long Island, New York-discussion. Journal of Sedimentary Petrology 53, 1014-1019.

Trincardi. F., Correggiari, A., 2000. Quaternary forced regression deposits in the Adriatic basin and the record of composite sea-level cycles. In: Hunt, D. Gawthorpe, R.L. (Eds.) Sedimentary response to Forced Regressions. Geological Society London, Special Publication 172, 245-269.

Trincardi, F., Argnani, A. (Eds.), 2001. Note Illustrative della Carta Geologica dei mari italiani alla scala 1:250.000 - Foglio NL33-10 Ravenna. S.EL.CA., Firenze, 108 pp.

Trincardi, F., Correggiari, A., Roveri, M., 1994. Late Quaternary transgressive erosion and deposition in a modern epicontinental shelf: the Adriatic Semi-enclosed Basin. Geo-Marine Letters 14, 41-51.

Trincardi, F., Asioli, A., Cattaneo, A., Correggiari, A., Langone, L. 1996. Stratigraphy of the late-Quaternary deposits in the Central Adriatic basin and the record of shortterm climatic events. In: Guilizzoni P., Oldfield F.L. (Eds.), Palaeoenvironmental Analysis of Italian Crater Lake and Adriatic Sediments (PALICLAS). Mem. Ist. Ital. Idrobiol. 55,39-64.

Trincardi, F., Cattaneo, A., Correggiari, A., Penitenti, D., Roveri, M., Asioli, A., Taviani, M., 2004. Geological mapping of the Italian seafloors: The Adriatic Project. In: Pasquarè, G., Venturini (Eds.), Mapping Geology in Italy (APAT). S.EL.CA., Firenze, 51-60. 
1002 Van Goor, M.A., Zitman, T.J., Wang, Z.B., Stive, M.J. F., 2003. Impact of sea-level 1003 rise on the morphological equilibrium state of tidal inlets. Marine Geology 202, 2111004227.

Waschbusch, P.J., Royden, L.H., 1992. Spatial and temporal evolution of foredeep basins: lateral strength variations and inelastic yielding in continental lithosphere. Basin Research 4, 179-196.

Weltje, G.J., Prins, M.A., 2003. Muddled or mixed? Inferring palaeoclimate from size distributions of deep-sea clastics. Sedimentary Geology 162, 39-62.

Yu, S.C., Decouttere, C., Berlamont, J., 1998. Storm surge simulations in the Adriatic Sea. In: Gambolati G. (Ed.). CENAS. Coastline Evolution of the Upper Adriatic Sea due to Sea Level Rise and Natural and Anthropogenic Land Subsidence. Kluwer Academic Publishers, the Netherlands, 207-232. 
1017

1018

1019

1020

1021

1022

1023

1024

1025

1026

1027

1028

1029

1030

1031

1032

1033

1034

1035

1036

1037

1038

1039

1040

1041

1042

1043

1044

1045

1046

1047

1048

1049

1050

1051

1052

1053

1054

1055

1056

1057

1058

1059

1060

1061

1062

1063

1064

1065

1066

\section{FIGURE CAPTIONS}

Figure 1

Overview of the study area. The greyscale shows high (dark grey) and low (light grey) lying areas. Redrawn after Kettner and Syvitski, in press.

\section{Figure 2}

(A) Overview of the Adriatic shelf with 3-D shaded bathymetry of Sites A and B. Cores used for radiocarbon dating are indicated by closed circles. Cores shown in this paper are indicated by black stars. (B) Bathymetric maps of the two sites with locations of seismic profiles.

\section{Figure 3}

Merged eustatic sea level curve (line) and associated radiocarbon datings based on Liu and Milliman (2004) and Fleming et al. (1998). Melt water pulses 1A and 1B are indicated.

Figure 4

(A) Schematic longitudinal section of the Adriatic Sea used in the 1-D palaeo-tidal reconstruction. (B) Results of the 1-D model. The left-hand side shows a series of M2 and $\mathrm{K} 1$ tidal amplitudes. The curves start at $\mathrm{x}=0$ and extend to palaeo-coastline positions corresponding to various sea levels. On the right hand side, model results are compared to measurements of present-day M2 and K1 tides (data from Polli, 1960).

\section{Figure 5}

Reconstructed palaeo-environmental conditions on the Northern Adriatic shelf during post-glacial sea-level rise. The horizontal scale represents the coastline position during the late Quaternary transgression. (A) Maximum cumulative tidal amplitude; (B) Palaeo-wave climate; (C) Rate of sea-level change; (D) Modern bathymetry of the Adriatic shelf, with locations of the isolated sediment bodies indicated by the white areas with black stars; (E) Palaeo-coastline positions based on modern bathymetry and eustatic sea-level curve shown in Figure 3. Radiocarbon datings are from Correggiari et al., 1996a; Trincardi and Argnani, 2001, and unpublished ISMAR data (see Figure 2 for locations).

\section{Figure 6}

Shallow seismic profiles of the deep isolated sediment body at Site A. The solid white line separates the pre-transgressive (below) from the post-transgressive (above) sediment. The dotted white line in profile II highlights lateral migration structures of a channel. Profile locations indicated in Figure 2 (data from Cattaneo et al., 2001).

Figure 7

Interpreted sedimentological data of the deep isolated sediment body at Site A. For location see Figures 2 and 6 (data from Cattaneo et al., 2001).

\section{Figure 8}

Schematic cross-section of the overstepped barrier system of the shallow isolated sediment body at Site B. Vertical scale represents the water depth. Sections redrawn after Cattaneo et al. (2001). 
Figure 9

Shallow seismic profiles of the low-gradient plateau at Site B. Profile VII and IX show pre-transgressive channel deposits. The arrows in profile VII indicate the direction of lateral channel migration. Profile VII illustrates the transgressive deposits. For location of the profiles see Figure 2 (data from IDROSER, 1985, 1990).

Figure 10

Grain-size data and lithofacies of seven cores taken at different water depths (see Figure 2 for locations). Vertical lines mark the occurrence of specific grain-size ranges (end members). Sucession of facies is typical for transgressive barrier-lagoon systems.

\section{Figure 11}

Mean grain size $(\mu \mathrm{m})$ versus skewness (calculated in phi units) in all cores for three lithofacies: (A) clayey backbarrier deposits, (B) silty to sandy backbarrier deposits and (C) shoreface sands. Core locations and descriptions are shown in Figures 2 and 10. See text for explanations.

\section{Figure 12}

Mean grain size $(\mu \mathrm{m})$ versus the rate of sea-level rise for three lithofacies: (A) clayey backbarrier deposits, (B) silty to sandy backbarrier deposits and (C) shoreface sands. Core locations and descriptions are shown in Figures 2 and 10. See text for explanations.

Figure 13

Basic concepts of the numerical model BarSim (Storms et al., 2002; Storms, 2003).

\section{Figure 14}

Example of a BarSim run for a situation comparable to the coastal evolution history at site B. The upper panel shows that initially no barrier was present at the steep part of the edge of the plateau. As the barrier formed and migrated landward (panel 2-4) the depth and width of the backbarrier rapidly increased which led to overstepping (panel $5)$.

Figure 15

BarSim simulations for a transgressive wave-dominated (Scenario 1) and tidedominated (Scenario 2) barrier-lagoon system. Simulated time interval $=5000$ years; relative sea-level rise $=20 \mathrm{~m}$. Tidal amplitude in Scenario $2=3 \mathrm{~m}$. Gray-scale represents mean grain size $($ dark $=$ coarse, light $=$ fine $)$. Synthetic cores at final coastline positions are shown on the right. (C) Super-imposed final morphologies of the two systems. 
Figure 1

1110

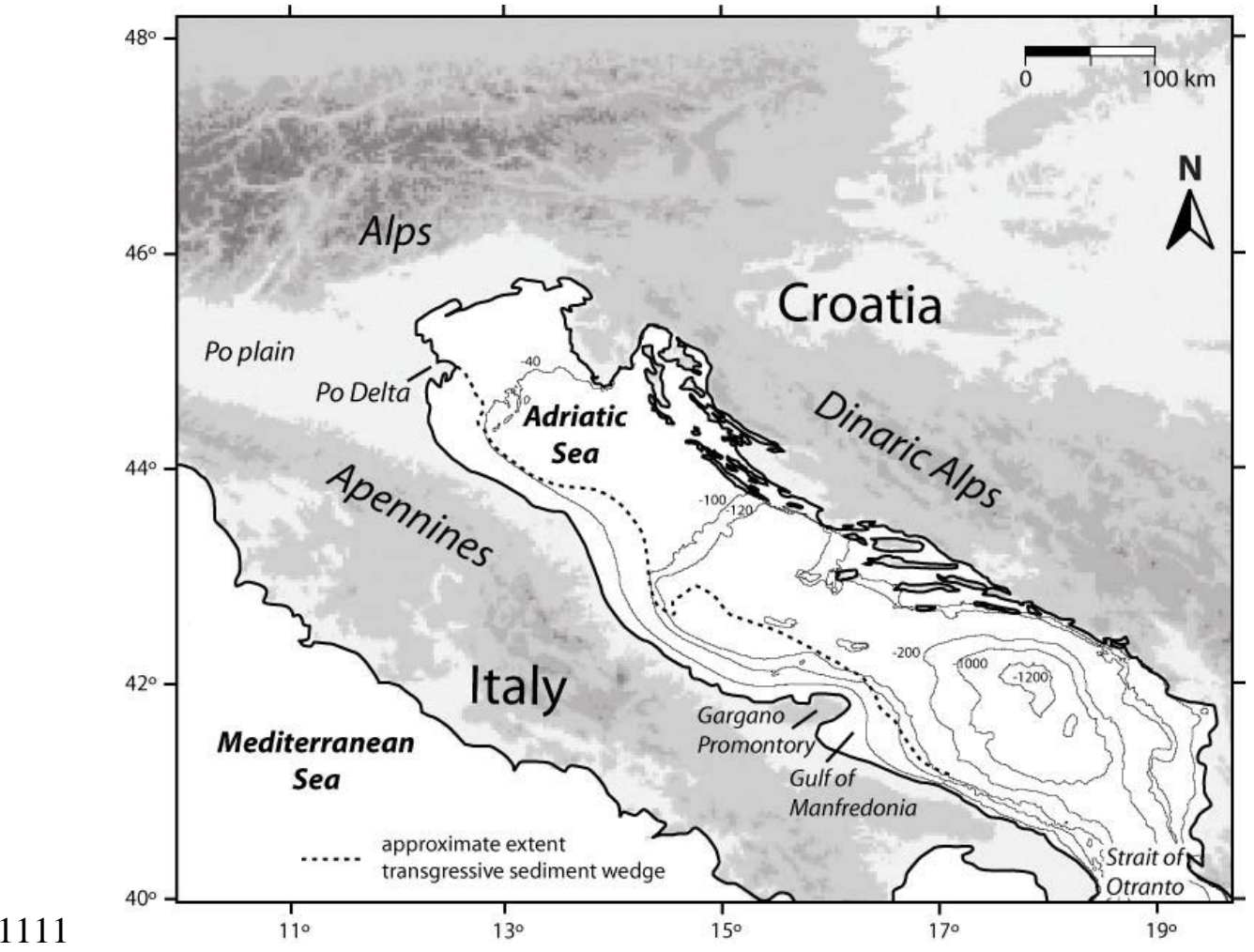


1112

1113

Figure 2

(A)
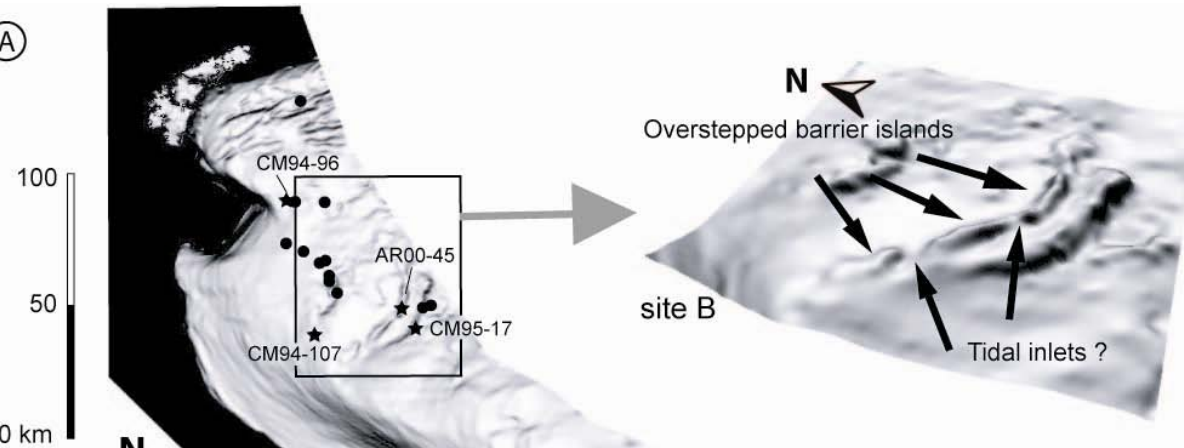

$\mathrm{km}$

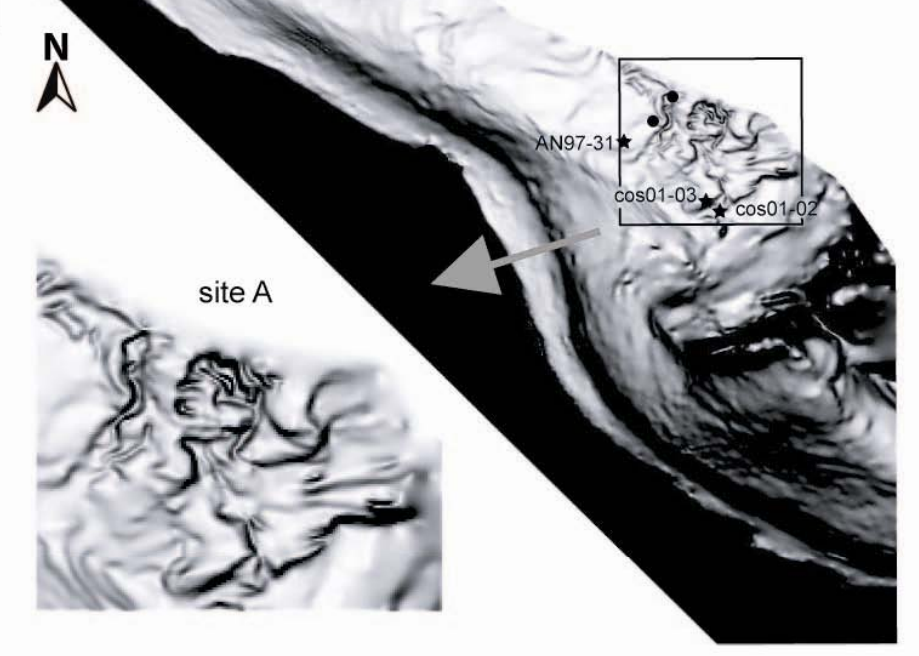

(B)

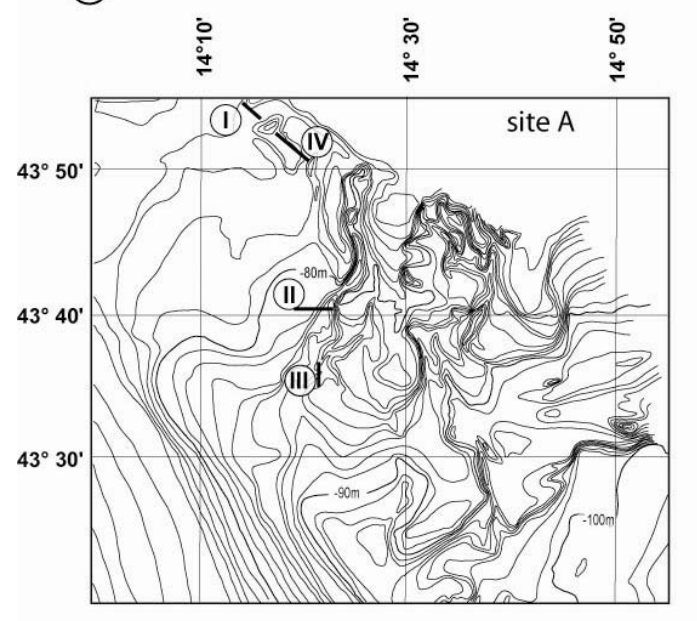

1114

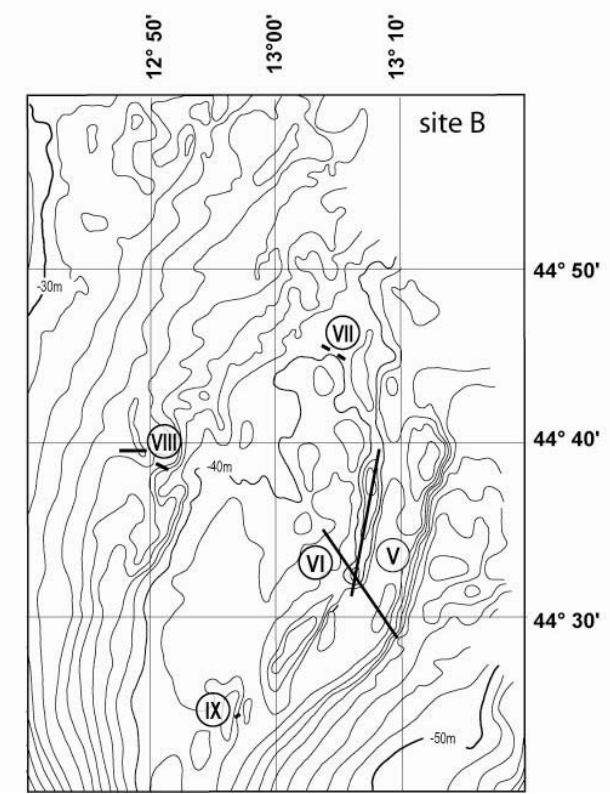


1115 Figure 3

1116

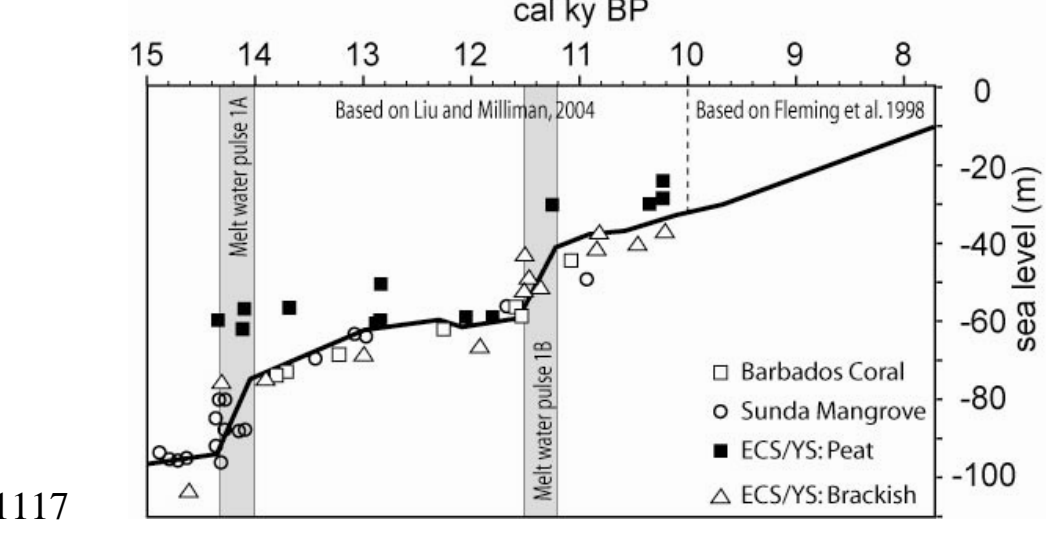


1118 Figure 4

1119

(A)

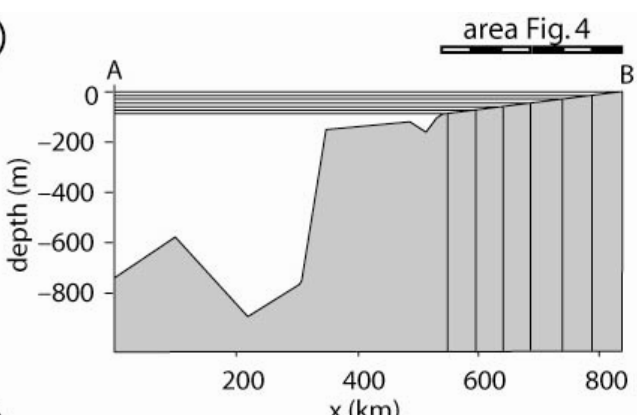

(B)
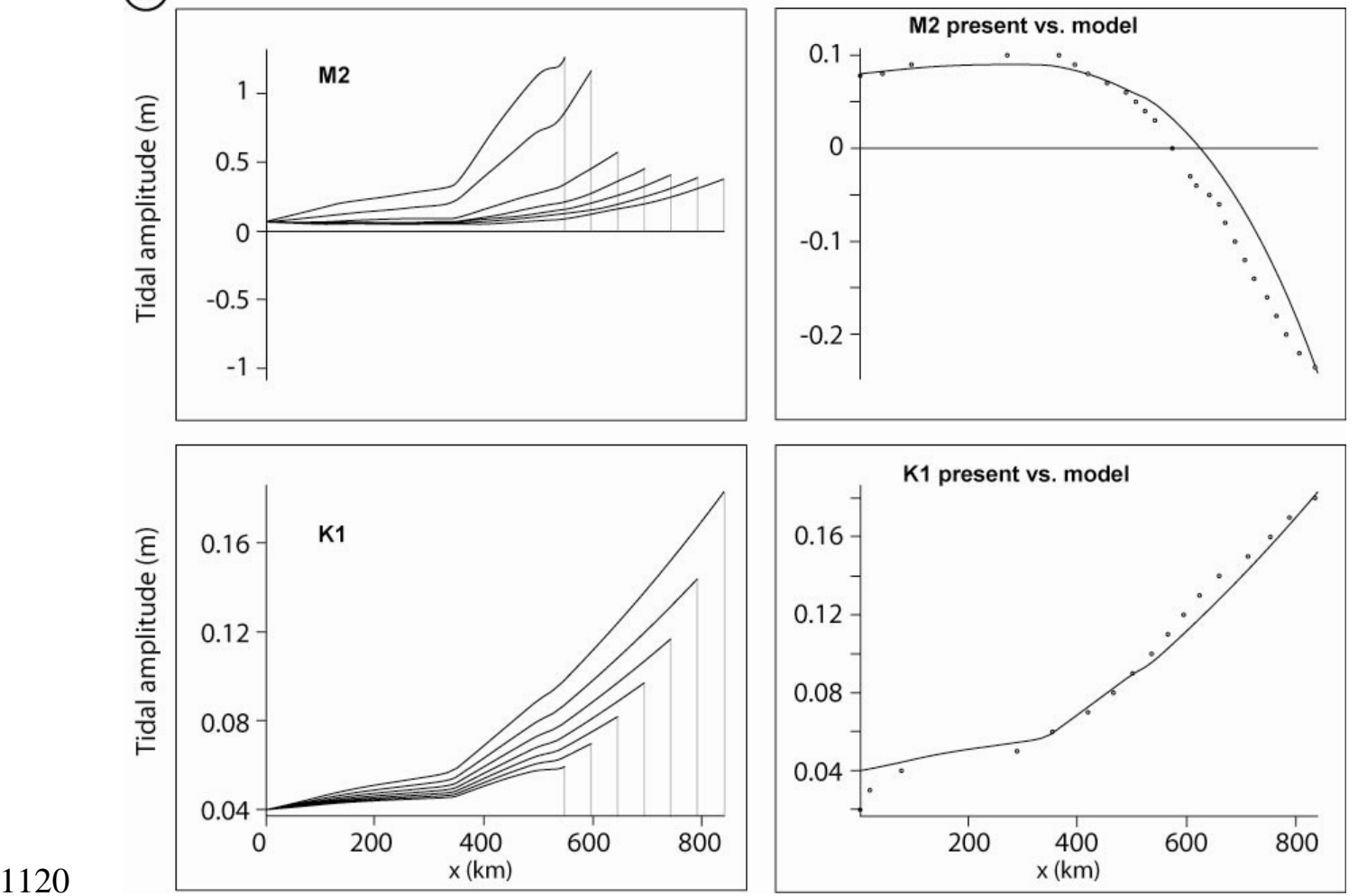
1121 Figure 5

1122
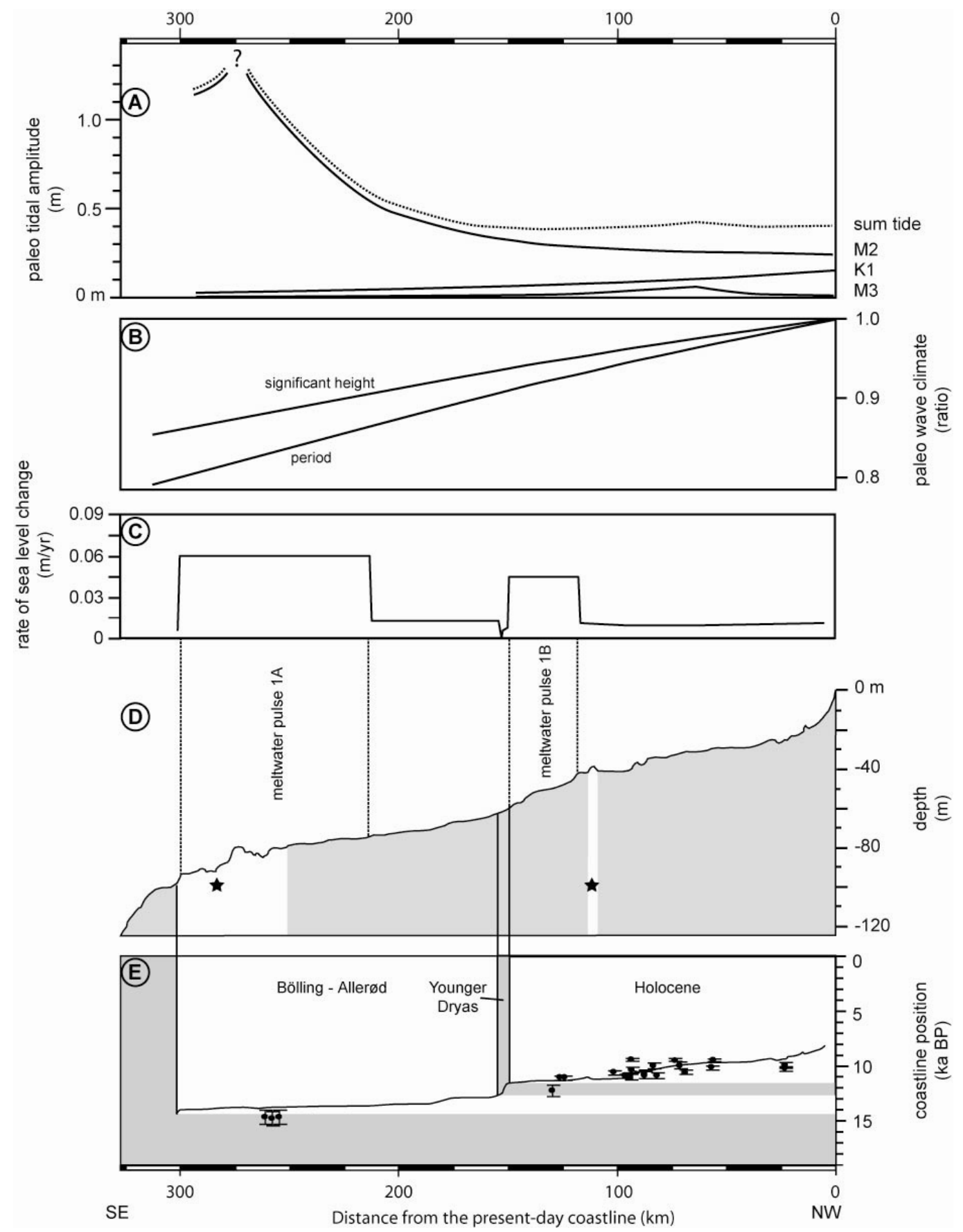

1123 
1124 Figure 6

1125
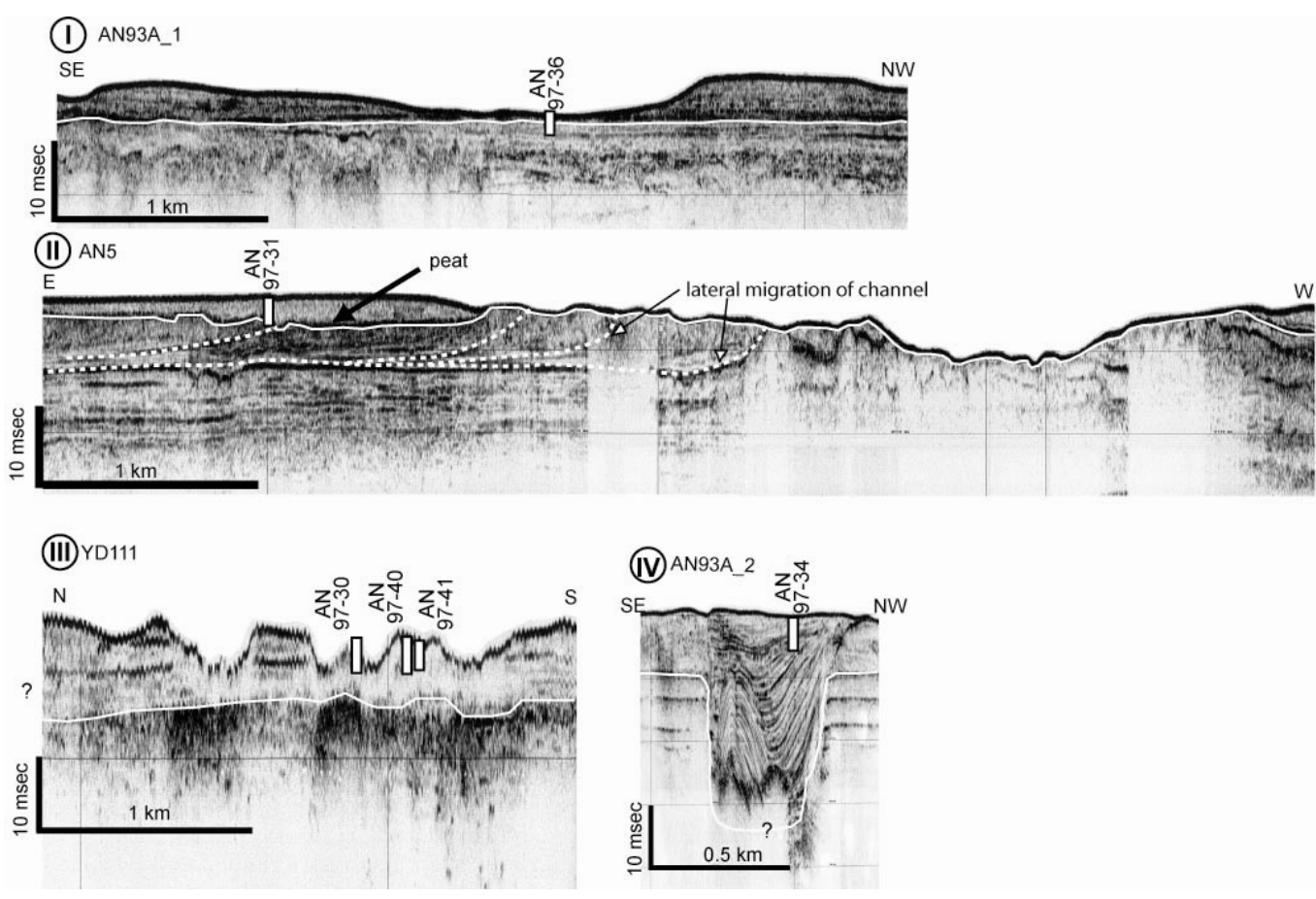

1126 
$1127 \quad$ Figure 7

1128

1129

1130

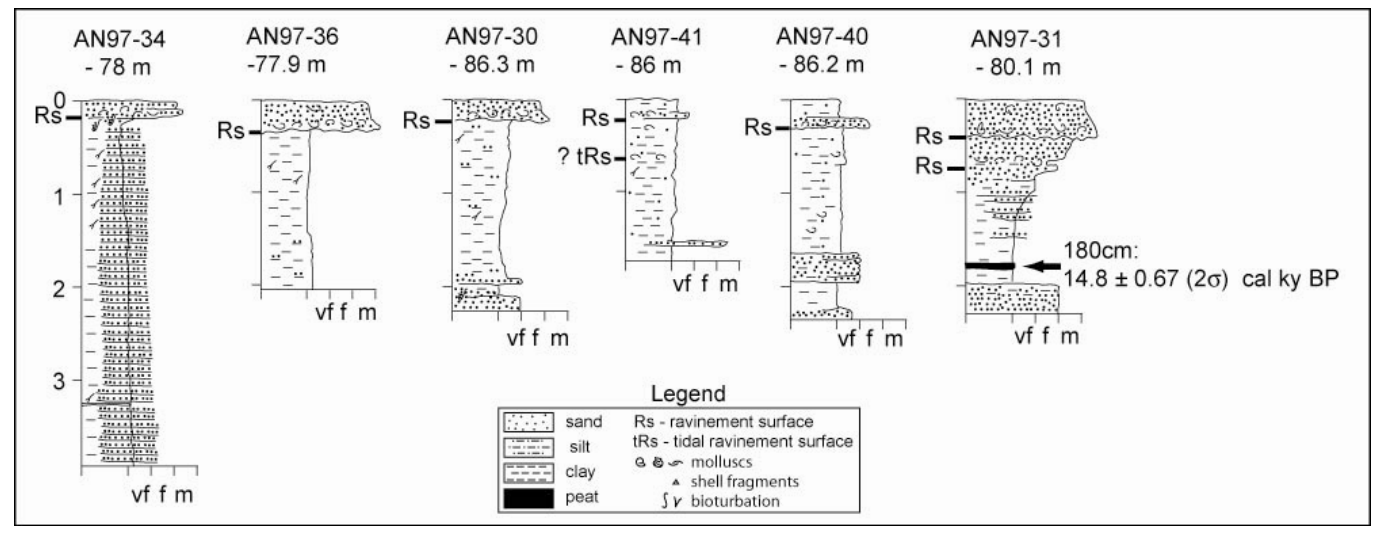


1131 Figure 8

1132

1133

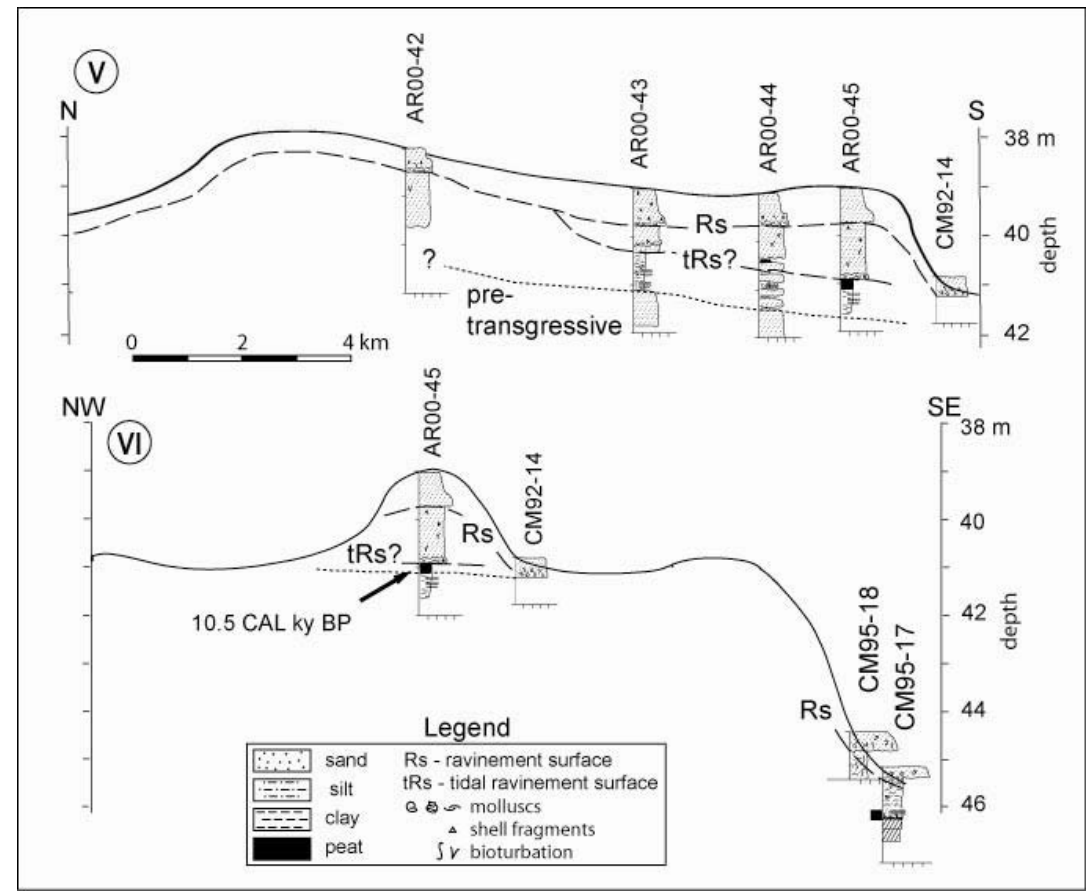


1134

Figure 9

1135
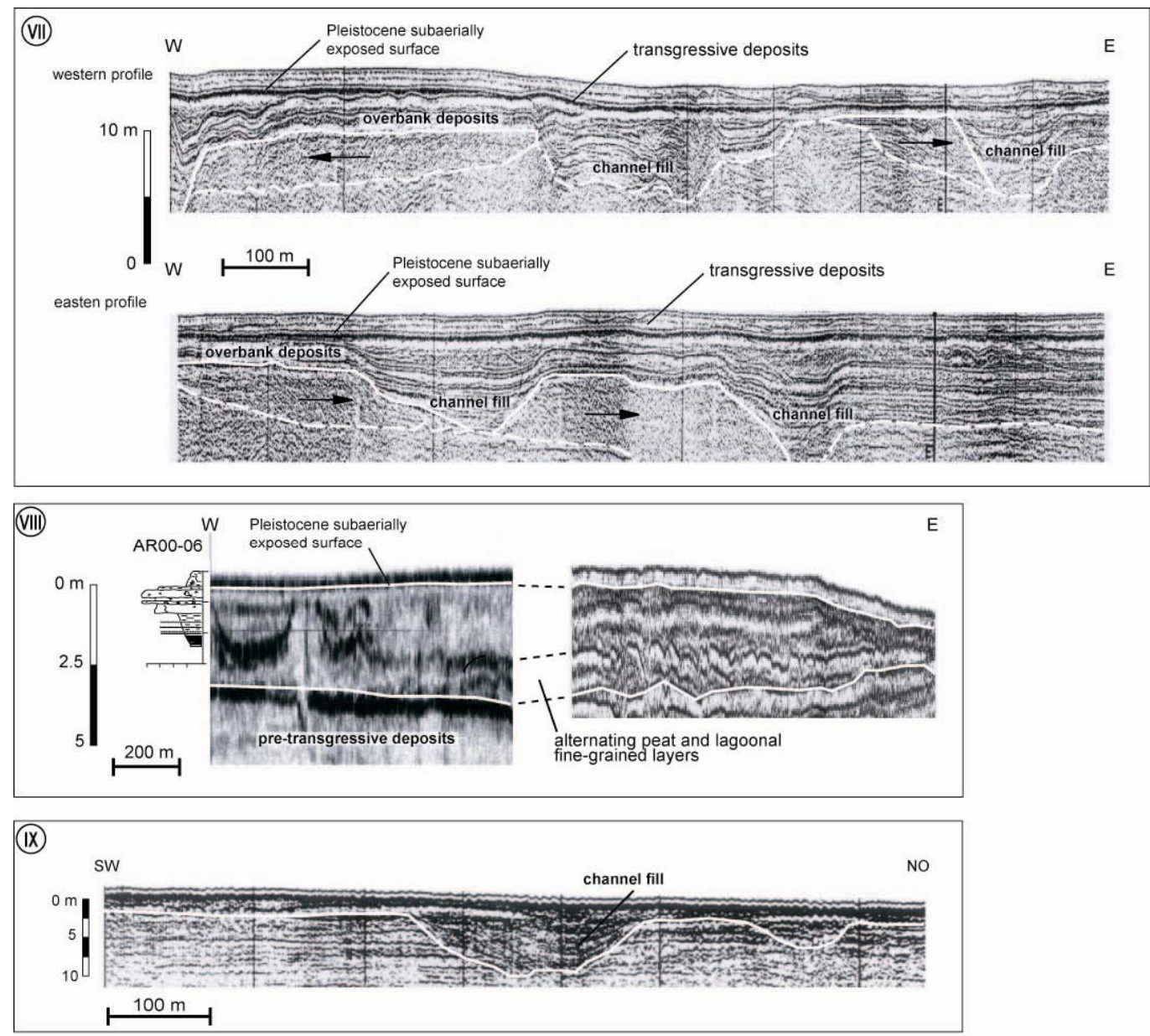

1136 
1137

Figure 10

1138

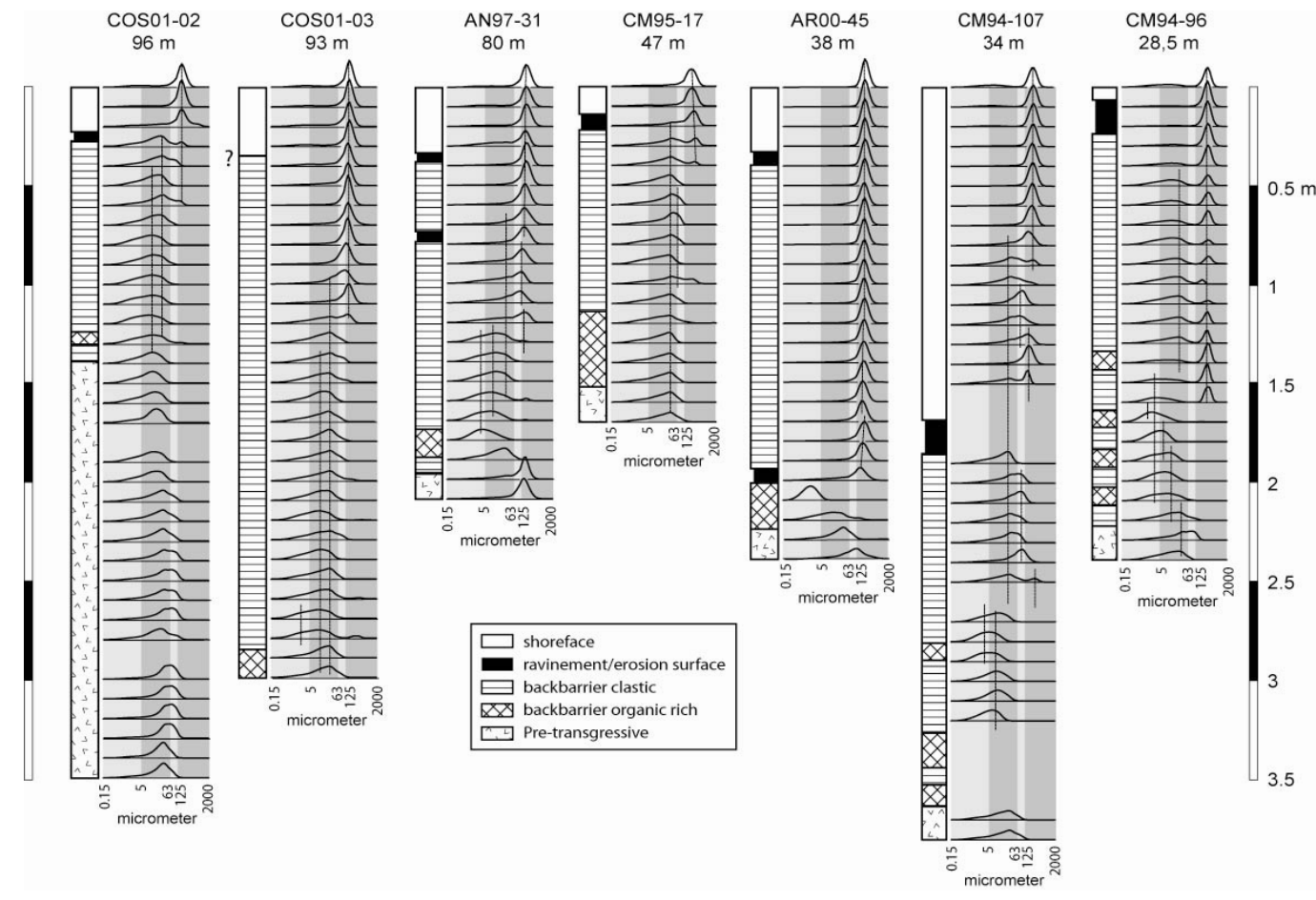

1139 
1140

1141

Figure 11
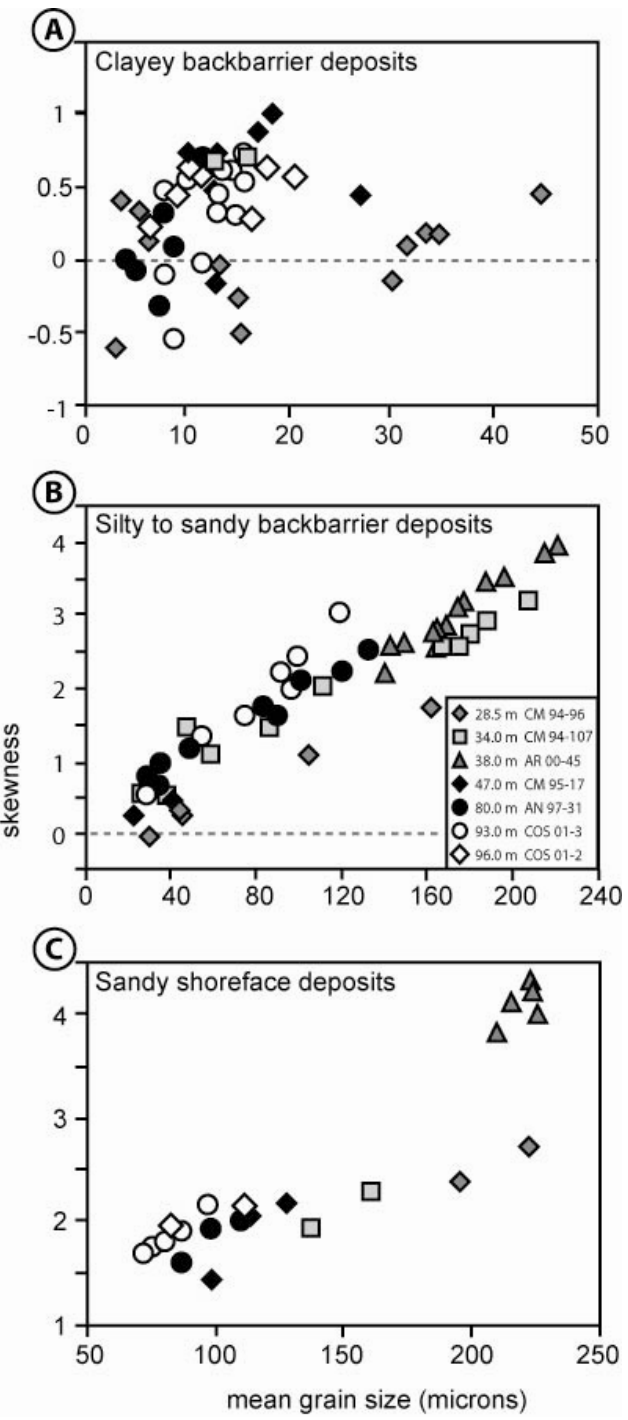

1142 
$1143 \quad$ Figure 12

1144
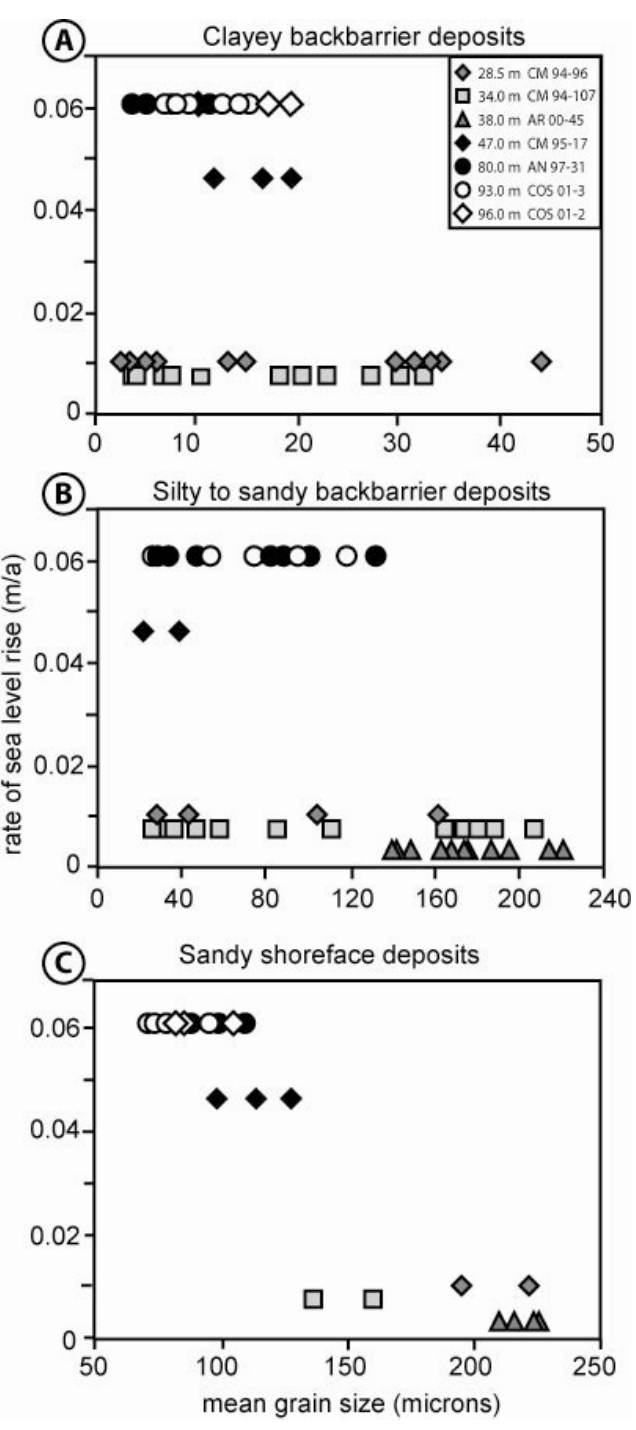

1145 
1146

1147

Figure 13

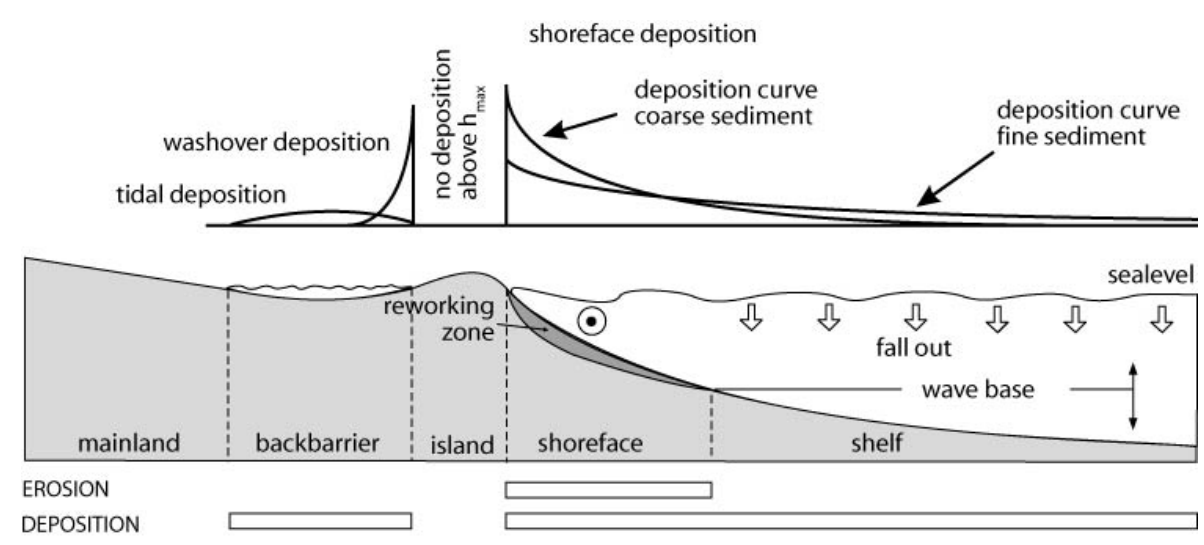


Figure 14

1150

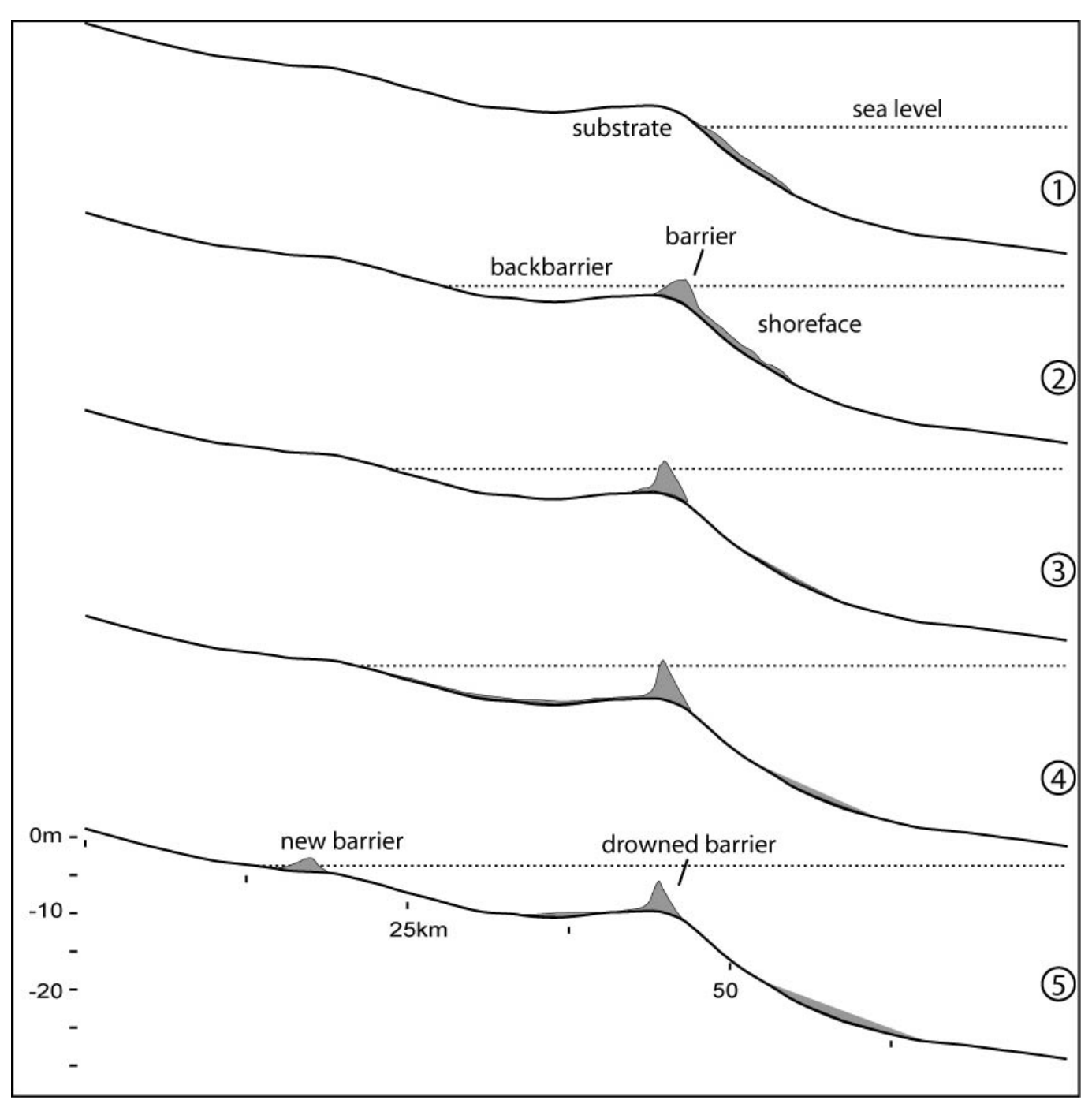

1151 
1152 Figure 15

1153
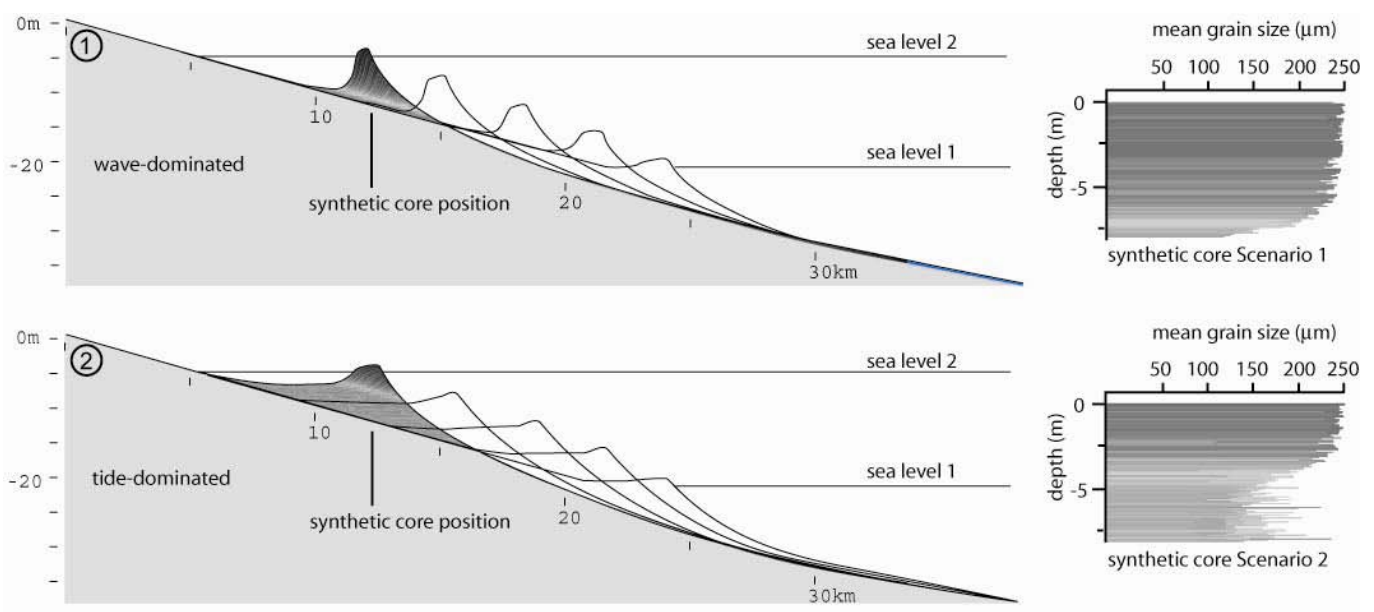

1154

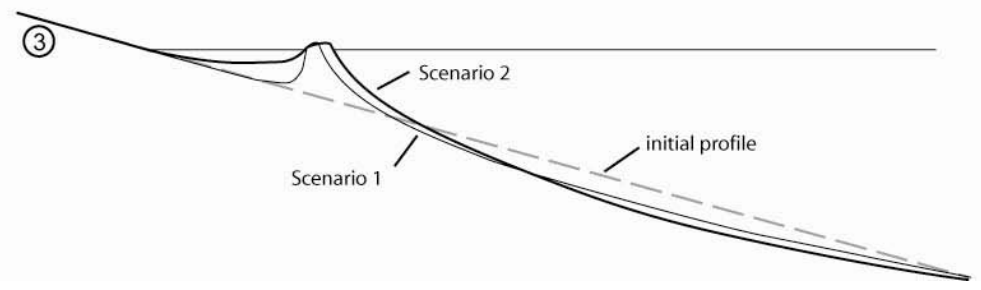

